
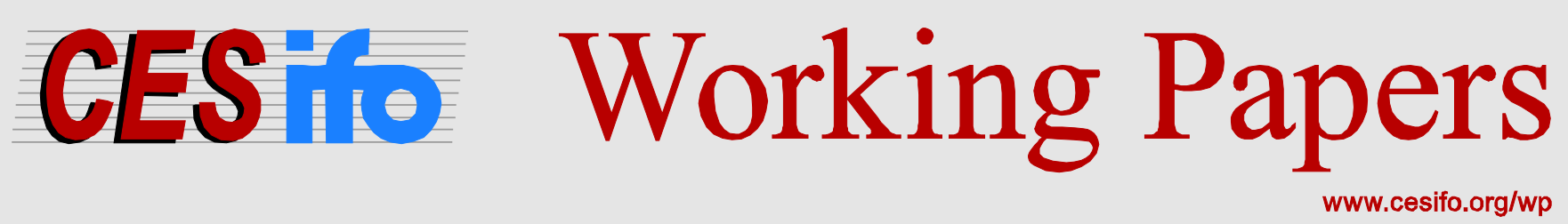

\title{
The Location of Cross-Border Mergers \& Acquisitions in the USA
}

\author{
Steven Brakman \\ Harry Garretsen \\ Charles Van Marrewijk
}

\author{
CESIFO WORKING PAPER NO. 5331 \\ CATEGORY 12: EMPIRICAL AND THEORETICAL METHODS \\ ORIGINAL VERSION: APRIL 2015 \\ THIS VERSION: DECEMBER 2015
}

An electronic version of the paper may be downloaded

- from the SSRN website:

- from the RePEc website:

- from the CESifo website:

wWw.SSRN.com

Www.RePEc.org

www.CESifo-group.org/wp 


\title{
The Location of Cross-Border Mergers \& Acquisitions in the USA
}

\begin{abstract}
The research on the location choice for Foreign Direct Investment (FDI) is traditionally restricted to a choice between countries. The within-country location choice is less prominent in the literature. If within-country location decisions are considered it is mostly limited to Greenfield investments. The vast majority of FDI, however, takes place in the form of crossborder Mergers \& Acquisitions (M\&As), and for this form of FDI (empirical) research on location choice within countries has been neglected. In this paper we analyze the within country location-target selection of M\&As in the USA. By introducing location choice, and applying the consequences of super-modularity of the model we estimate the within country location choice of (cross-border) M\&As. Using a detailed firm level data set for all manufacturing sector M\&As across the USA for the period 1985-2012, we compare location choices of cross-border M\&As to that of national M\&As. We find that: cross-border M\&As are more spatially concentrated than national M\&As, that cross-border M\&As sort into larger agglomerations across the USA than national M\&As, and that for both forms of M\&As location specific market access in the USA as well as access to the rest of the world (through transport hubs) are key drivers for target selection.
\end{abstract}

JEL-Code: F100, F120, L130.

Keywords: cross-border mergers and acquisitions, location choice, agglomeration.

\author{
Steven Brakman* \\ University of Groningen \\ Faculty of Economics \& Business \\ P.O. Box 800 \\ The Netherlands - 9700 AV Groningen \\ s.brakman@rug.nl
}

\author{
Harry Garretsen \\ University of Groningen \\ Faculty of Economics \& Business \\ The Netherlands - 9700 AV Groningen \\ j.h.garretsen@rug.nl
}

\author{
Charles Van Marrewijk \\ International Business School Suzhou \\ Xi'an Jiaotong - Liverpool University \\ PR China - Suzhou, 215123 \\ charles.vanmarrewijk@xjtlu.edu.cn
}

*corresponding author

First version: October 2014, this version: December 2015.

We would like to thank Julia Swart for assistance with the Thomson data. An earlier and rather different version of this paper was presented at the 59th NARSC conference in Ottawa, November 2012, and the "Nations and Cities/Regions after the Great Recession” conference, Erasmus University Rotterdam, December 2012. We would like to thank Cristian Bogmans, Marius Bruehlhart, Keith Head, Peter Neary, Enrico Pennings, Klaus DeSmet, Mark Partridge, Bart Los, Alexander Whalley and participants at these conferences and at various seminars for useful comments and suggestions. 


\section{INTRODUCTION}

The vast majority of foreign direct investment (FDI) takes place in the form of crossborder mergers and acquisitions (M\&As), see Evenett (2004). Analyzing the determinants and consequences of M\&As is part of a large and growing literature in both (international) economics and (international) business. In economics, the dominant industrial organization (IO) literature does not stress the cross-border aspect of M\&As, but instead concentrates on national M\&As (Salant et al., 1983; O’Brien and Shaffer, 2005; Egger and Hahn, 2010). A relatively small literature explicitly tries to include the cross-border aspect of M\&As, but neglects the role of country-wide factors that are central in international economics and international business to explain the structure and variation of cross-border transactions (Anand and Delios, 2002; Nocke and Yeaple, 2007, 2008, Bertrand and Zitouna, 2006; Fugmagalli and Vasconcelos, 2009, Halvorsen, 2012).

The impact of country wide differences on cross-border M\&As is taken explicitly into account by Neary $(2004,2007)$ who focuses on differences in comparative advantage between countries in a general equilibrium model to explain the occurrence of crossborder M\&As. Empirical support for this idea is found by Brakman et al. (2013), see also Blonigen et al. (2014). In the international business literature - ever since the introduction of Dunning's Ownership-Location-Internalization (OLI) framework - the mode of foreign entry and the choice of a foreign location have been central, but not explicitly modelled, as the OLI framework is more a taxonomy of relevant elements for location choice than a model (see for example Dunning, 2000). ${ }^{2}$

For both strands of literature: the modern international business and international economics literature, however, whenever the location of cross-border M\&As is taken into account, it usually refers to the host country as a whole. The within country location choice is typically not analyzed. This amounts to assuming that if foreign firms have decided to engage in an M\&A they choose a country but are indifferent regarding the target location within that country. This observation is the starting point for the present paper. In contrast to this observation with respect to cross-border M\&As, the within country location choice with respect to greenfield FDI has been analyzed in depth. The seminal study by Head et al. (1995) was pivotal, and initiated a large and growing body of literature; see for example Fontagne and Mayer (2005); Basile et al., (2008); Defever, (2006); or Mataloni, (2011). Similar analyses for crossborder M\&As are largely absent and this is striking because the bulk of FDI is in the shape of cross-border M\&As. A priori, there is no reason to assume that the location decision of greenfield investments and M\&As are similar. M\&As, by definition, merge with or acquire existing firms at a specific location, whereas greenfield investments can, in principle, locate anywhere.

\footnotetext{
${ }^{2}$ In the international business literature this omission has been noted; see for instance Beugelsdijk et al. (2010) or Iammarino and McCann (2013) for a plea to include the within-country location choice of FDI.
} 
In this paper we analyze the location patterns of cross-border and, as a benchmark, national M\&As within the USA. We use the global mergers and acquisitions database of Thomson Financial Securities Data that includes location information on M\&As. We will analyze all manufacturing cross-border and national M\&As within the USA for the period 1985-2012. Our data set covers 192,000 individual M\&As. Building on and extending a model by Guadalupe et al. (2012), adapted to include location choice, we provide three novel pieces of empirical evidence. First, we give new descriptive statistical evidence by comparing the location patterns of M\&As with those of US firms in general using the Ellison-Glaeser index (Ellison and Glaeser, 1997, 1999). Second, we use two recent tests - an elasticity test and a pairwise comparison test suggested by Davis and Dingel (2014) to show that cross-border M\&As choose different - larger - locations than national M\&As. These tests are based on the supermodularity of our model set-up. Third, we estimate the link between location patterns and location determinants for both national and cross-border M\&As. We find that M\&As in general are more spatially concentrated than other US firms and that crossborder M\&As are indeed more spatially concentrated than national M\&As. We also establish that cross-border M\&As sort into larger agglomerations across the USA than national M\&As, supporting the implication from Davis and Dingel (2014). And, finally, with respect to the determinants of cross-border M\&As, our estimations indicate that market access in the USA as well as, through the vicinity of an international airport, access to the rest of the world are key drivers for the target selection by acquiring firms.

The structure of the paper is as follows. In Section 2 we motivate the main hypotheses of the paper. The data are illustrated in section 3, and the data appendix. Sections 4-6 present the main findings: section 4 applies the Ellison-Glaeser index to the data, section 5 provides evidence for the elasticity test, and pairwise comparison tests, and section 6 links the value of M\&As to location specific variables. Section 7 concludes.

\section{A MODEL of LOCATION-TARGET SELECTION}

Our model assumes that the M\&A decision as well as the host country decision, as a mode of entry, have already been made but that the acquiring firm still has to choose a location and thus a target within the host country. The (partial) model motivates the hypotheses and selection of variables. We do not model general equilibrium aspects of M\&As related to, for example, economy wide characteristics as in Neary (2007). We also do not analyze whether an M\&A is preferred over other modes of entry, as in Nocke and Yeaple $(2007,2008)$ who distinguish between three modes of entry: exports, greenfield FDI, and (cross-border) M\&As. The key characteristic of their model is the distinction between 'mobile' and 'non-mobile' characteristics or 'capabilities.' The motivation for this distinction focuses on the mobility of some characteristics (like technology) and the immobility of other characteristics (like location specific knowledge of the local market; see Anand and Delios, 2002, for an 
empirical analysis of a similar concept, who focus on local marketing knowledge, and knowledge of local institutions). The distribution of these capabilities over firms determines the mode of entry. Acquirers are efficient in certain mobile capabilities, but lack some non-mobile characteristics. Target firms can offer these non-mobile capabilities and make M\&As profitable; an M\&A combines the two capabilities - the mobile capabilities of the acquirer, and the non-mobile capabilities of the target. This synergy is explicitly modelled in Nocke and Yeaple (2007, 2008). The fact that nonmobile capabilities are (in principle) known and can be assessed by acquirers before a takeover makes the model set-up different from Greenfield investments. ${ }^{3}$ The question then becomes, what can be used to measure the local non-mobile capabilities of a target firm? A location specific answer is agglomeration rents, as these are nonmobile and location specific. This is the motivation for our model and links our discussion of M\&As to that of Head et al. $(1995,1999)$ with respect to greenfield FDI. They find that industry relevant and location specific agglomeration rents are important for greenfield FDI location decisions. In general, this conclusion has been corroborated by subsequent literature (see, Kim et al., 2003, Blonigen et al. 2007, Bobonis and Shatz, 2007, Brühlhart and Mathys, 2008, Halvorsen, 2012, Alfaro and Chen, 2014; see Antras and Yeaple, 2014, for a survey). However, similar results for cross-border M\&As have yet to be established.

Our model builds on Guadalupe et al. (2012). The difference between our model and their model is that they focus on optimal levels of innovation, whereas we focus on location choice which is absent in their model. In both models, once the M\&A has taken place, the target becomes as efficient as the acquirer (see also Neary, 2007). This motivates why we do not look at differences between acquirer and target productivity explicitly. ${ }^{4}$ The backbone of the model is the standard Dixit-Stiglitz monopolistic competition model extended with Melitz (2003) type productivity differences. The key assumption in the model - which is subject to our tests - is that cross-border M\&As sort into larger locations than national M\&As. The reason is that cross-border M\&As have to overcome larger entry costs and larger locations offer larger agglomeration rents. This enables acquiring firms to cover the (larger) entry costs. However, these larger markets are also characterized by higher land and housing prices, and more intense congestion than smaller locations, which also (adversely) affects location choice (see Glaeser, 2008 for a discussion).

Empirical evidence shows that entering a foreign market is indeed more expensive than entering the domestic market (see Helpman et al., 2004, for empirical support).

\footnotetext{
${ }^{3}$ Furthermore, Greenfield investments change the local economy (additional labor demand which might drive up wages, affect local congestion, etc) whereas for M\&As these variables are - at least to some extent - exogenous. Furthermore the location of a M\&As is known which might not always be the case for a Greenfield investment (ideal locations might already be occupied).

${ }^{4}$ See Brakman et al. (2013) for an explicit discussion of acquirer and target differences with respect to productivity.
} 
These costs carry over to parent firms that are engaged in M\&As. Empirical research also shows that firms in larger agglomerations or cities are more productive than firms in smaller agglomerations. In general, two separate reasons can be responsible for this relation: sorting of more productive firms and workers into larger agglomerations and agglomeration economies, such as knowledge spillovers which are covered under the general term agglomeration economics. Baldwin and Okubo (2006) show, for example, that more productive firms sort into larger agglomerations or cities because firms benefit from forward and backward linkages, and only the most productive firms can cope with more intense competition in larger markets. More productive workers also tend to sort into larger agglomerations making firms more productive. (Combes et al., 2008b). In a recent study, Combes et al. (2012) try to separate sorting from agglomeration economies. They find, using a detailed dataset on French firms, that sorting is relatively unimportant compared to agglomeration economies. In a similar vein, De la Roca and Puga (2012) find that sorting of more productive workers is not the main reason that workers in large cities are more productive than in smaller cities; learning in bigger agglomerations seems to be a relatively more important factor. For our paper it is sufficient to note that firms in larger agglomerations are more productive than in smaller locations, no matter whether this is caused by sorting, agglomeration economies, or a combination of both forces; larger markets are home to more productive firms and workers. The existence of agglomeration economies is, however, undisputed. In a survey Melo et al. (2009) show that these agglomeration economies are in general positive.

In our set-up the problem reduces to motivating why firms in larger agglomerations or cities are relatively more attractive targets for (foreign) firms engaged in M\&As than firms in smaller agglomerations or cities. In the remainder we assume that foreign firms are more productive than national firms as they have to overcome larger entry costs (and the sorting process selects more productive firms), and that larger agglomerations offer higher agglomeration rents, but are also more expensive. These assumptions are motivated by the literature discussed above and our model framework shows that as a consequence cross-border M\&As should sort into larger locations than national M\&As. We proceed in two steps. In the first step we analyze under what conditions the sorting process is robust. Mrázová and Neary (2013) show that if (maximum) profits are super-modular, this sorting process holds in many cases, including ours. ${ }^{5}$ In the empirical tests we will use the empirical consequences of super-modularity. In the second step we will specify the profit function in a monopolistic competition setting, which motivates our choice of variables when it comes to the location determinants of M\&As.

Step 1: In their paper on super-modularity Mrázová and Neary (2013) use a profit function $\pi(c)$ which is continuous and strictly decreasing in $c$, where $c$ is a firm-

\footnotetext{
${ }^{5}$ Function $H$ is super-modular (in $x$ and $y$ ) if: $x \geq x^{\prime}, y \geq y^{\prime} \Rightarrow H(x, y) H\left(x^{\prime}, y^{\prime}\right) \geq H\left(x, y^{\prime}\right) H\left(x^{\prime}, y\right)$. See for some intuition the discussion below.
} 
specific cost parameter (inverse firm efficiency indicator). The firm contemplates serving a particular market at a fixed (entry) cost $F>0$. If the entry costs are higher than the profit level of the least efficient firms but lower than the profit level of the most efficient firms there is a cut-off level at which only the most efficient firms will enter the market (this is sorting as in Melitz, 2003). We do not observe firm efficiency directly in our paper, but show that the distribution of efficiency for cross-border M\&As is - on average - more efficient than national M\&As at a given location. All that is needed for this selection effect to hold is that $\pi(c)$ is decreasing in $c$.

In our setting, we let firm efficiency interact with location choice as measured by market access or market size $M$ at that location, such that the profit function $\pi(M, c)$ is continuous, strictly increasing in $M$ and strictly decreasing in $c$. Market entry is now related to a take-over of a firm at a certain location (M\&A). The costs $F$ rise as market size increases: $F=F(M)$. Moreover, we distinguish between two types of firms, domestic (national $=N$ ) firms and foreign (cross-border $=C B$ ) firms. In view of the discussion above, the takeover costs are higher for foreign firms because of the additional costs at a given location ${ }^{6}: F(M)+f$.

Figure 1 For a given location the CB cost range is smaller than the $N$ cost range

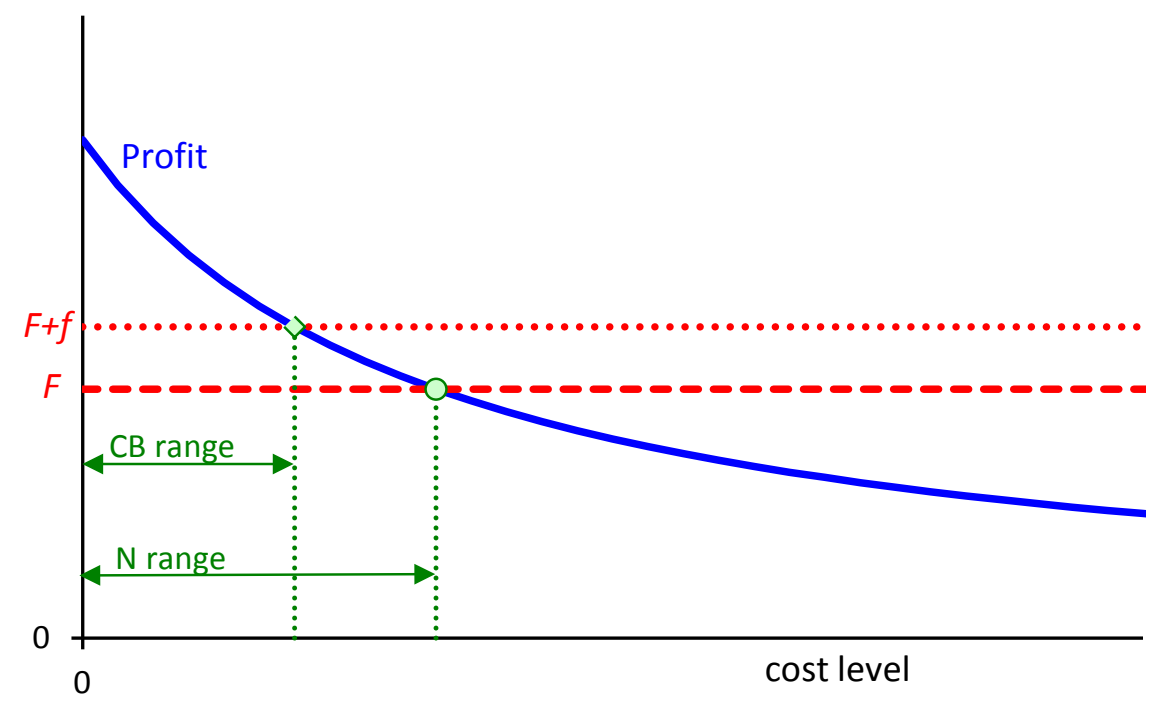

$\mathrm{N}=$ National; $\mathrm{CB}=$ Cross-Border

Note that:

(i) A takeover at a location is possible if the profits are larger than the takeover costs, requiring $\pi(M, c)>F(M)$ for national firms and $\pi(M, c)>F(M)+f$ for foreign firms. As Figure 1 illustrates, this implies that for a given location with market access $M$ the range of firms for which a takeover is profitable is larger for national firms than for foreign firms. For any given location foreign firms therefore need to be on average more efficient. Note also that in Figure $1 \mathrm{a}$

\footnotetext{
${ }^{6}$ Alternative specifications, in which $f$, for example, depends on market access $M$, are possible without affecting our main arguments and conclusions.
} 
change in market access $M$ does not only shift the cost line $F$ but also the profit function $\pi$.

(ii) Let 0 be the cost level for the most efficient firm and $\infty$ the cost level for the least efficient firm. If, for a given location with market access $M$, we have $F(M)>$ $\pi(M, 0)$ there is no incentive even for the most efficient firm to take over another firm. Some locations (with low market access) therefore may not be profitable for takeovers. This happens in Figure 1 when the profit curve is shifted down to intersect the vertical axis below point $F$.

(iii) Combining points (i) and (ii) above, we note that there may be locations (with low market access) where takeovers are possible for national firms but not for foreign firms, namely if $F(M)+f>\pi(M, 0)>F(M)$. This happens in Figure 1 when the profit curve is shifted down to intersect the vertical axis between points $F$ and $F+f$.

An acquiring firm contemplating a M\&A will look at all potential target firms in different locations in conjunction with its own cost level. First of all it is necessary that a takeover at a certain location is feasible, as discussed in (i)-(iii) above. However, this is not sufficient. The tradeoff between the firm's cost (acquirer efficiency) level and the location specific profitability associated with a take-over, is crucial for efficiency sorting of firms across locations.

Figure 2 A foreign firm with higher efficiency may choose the larger market

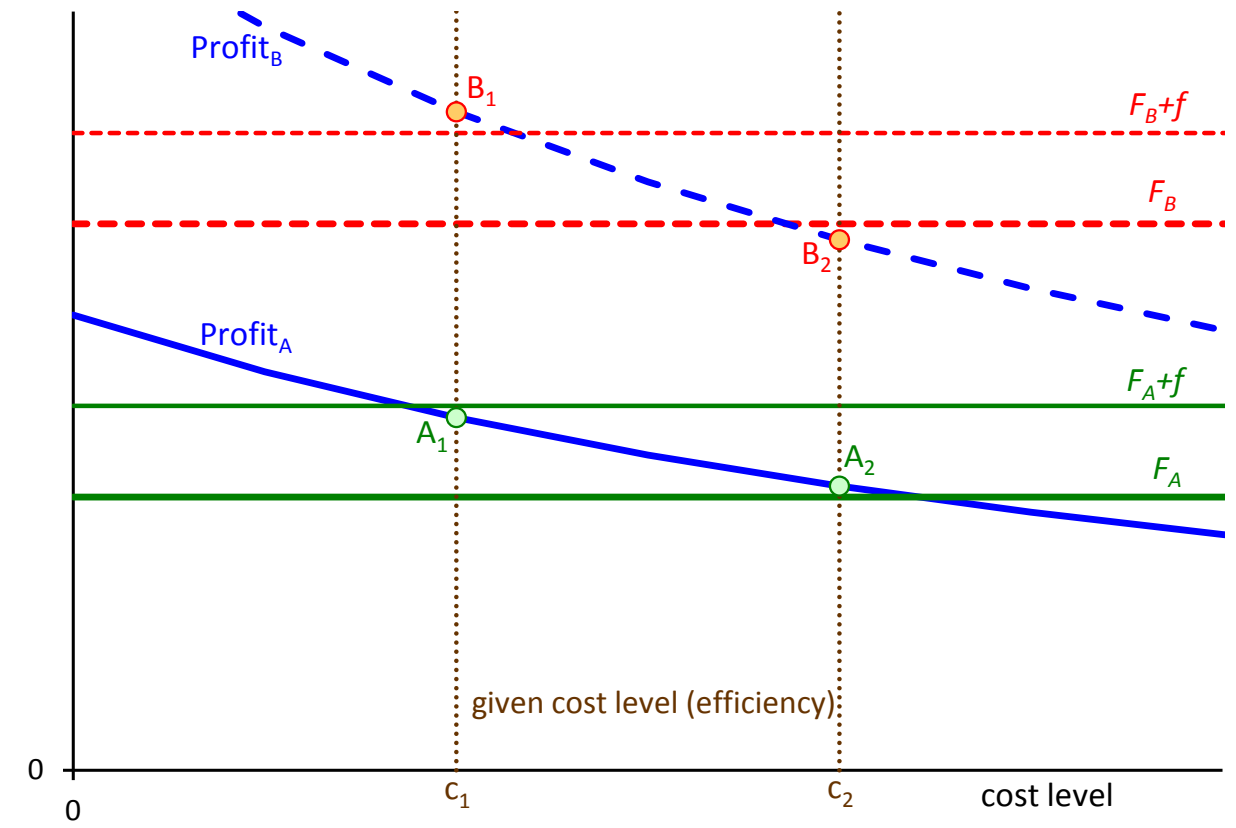

This is illustrated in Figure 2 for two firms, namely a foreign firm 1 with higher efficiency than national firm 2 (such that: $c_{1}<c_{2}$ ), confronted with two different market situations, namely situation A (using solid lines) and situation B (using dashed lines). The fixed takeover costs for foreign firms are larger by the amount $f$, as motivated above. 
We assume that market access is higher in situation B than in situation A, hence it must be the case that profit $_{B}>$ profit $_{A}$ in Figure 2. However, since larger locations also have higher land and housing prices or congestion costs this implies that the fixed costs for entering firms is also higher: $F_{B}>F_{A}$. The balance between profits and costs determines the attractiveness of a location. The profit level for cost levels 1 and 2 in situations $\mathrm{A}$ and $\mathrm{B}$ are given by points $A_{1}, A_{2}, B_{1}, B_{2}$, in Figure 2. Note that:

- The domestic firm with cost level $c_{2}$ can take over a firm in situation A (since $A_{2}>F_{A}$ ) but not in situation $\mathrm{B}$ (since $B_{2}<F_{B}$ ).

- The foreign firm with cost level $c_{1}$ can take over a firm in situation B (since $B_{1}>F_{B}+f$ ) but not in situation A (since $A_{1}<F_{A}+f$ ).

The more efficient foreign firm will therefore take over a firm in the larger market (situation B), while the less efficient domestic firm will take over a firm in the smaller market (situation A). Essentially, the less efficient domestic firm cannot pay the higher fixed costs in the larger market. This depends, of course, on how rapidly fixed costs rise as market size increases and how responsive profits are to a change in market access. Mrázová and Neary (2013) show, that an additional condition is sufficient for the sorting of more efficient firms in larger markets, as illustrated in Figure 2, to hold. Define $\tilde{\pi}(c, M)=\pi(c, M)-F(M)$. The sorting of more efficient firms is guaranteed if the function $\tilde{\pi}(c, M)$ is super-modular in $c$ and $M$ (for differentiable functions this holds if $\tilde{\pi}_{c M}(c, M) \geq 0$ ). Intuitively, super-modularity describes the complementarity between $c$ and $M$; other things equal, more efficient firms are relatively more profitable in larger locations (see Costinot, 2009 and Costinot and Vogel 2015, for a similar discussion in an international trade context). Interestingly, Davis and Dingel (2014) show how this complementarity can be tested using a so-called elasticity test and a pairwise comparison test between locations.

Step 2: next we will specify the profit function $\pi(c, M)$ for a specific, monopolistic competition setting in order to link our model to the location determinants of M\&As in our empirical analysis. Assume, like Guadalupe et al. (2012), that the target firm in location $j$ will become as productive as the parent firm after an M\&A, the value of the firm after a takeover equals $V_{j}^{N}\left(c, M_{j}\right)=\tilde{\pi}\left(c, M_{j}\right)$ for national firms and $V_{j}^{c b}\left(c, M_{j}\right)=\tilde{\pi}\left(c, M_{j}\right)-f$ for foreign firms. In a CES monopolistic competition context we typically have:

$$
\tilde{\pi}={\frac{(\sigma-1)}{\sigma^{\sigma}}}^{(\sigma-1)} \mathrm{E}_{j} \mathrm{P}_{j}^{(\sigma-1)}(\tau \mathrm{c})^{(1-\sigma)}-F_{j},
$$

where $\tau \geq 1$ is the standard iceberg transportation cost, $\sigma$ the elasticity of demand, $E_{j}$ is total expenditure on all varieties produced in $j$, and $P_{j}$ the (exact) aggregate price index associated with CES utility. The term $\mathrm{E}_{j} \mathrm{P}_{j}{ }^{(\sigma-1)}$ is called (real) market access (Brakman et al., 2009, ch. 8). As discussed in Mrázová and Neary (2013), cross- 
section comparisons instead of time-series comparisons allows us to treat the real market access as given for individual firms. ${ }^{7}$

\section{Hypotheses}

On the basis of the above model set-up, for the value of a firm after a M\&A we see that firms have to be (i) productive enough and (ii) select locations that offer sufficient market access or, more generally, agglomeration rents, to cover the location costs; it is the combination of these two elements that will make an M\&A viable. Because of the additional fixed costs $f$, for a given efficiency level, foreign firms are on average more efficient and tend to opt for larger locations. ${ }^{8}$ We can now formulate the following hypotheses:

\section{Hypothesis 1:}

M\&A activity is not distributed randomly across space; some locations attract M\&As while others do not; locations with 'zero' (cross-border) M\&A observations are possible.

Hypothesis 2a:

Higher entry costs for cross-border M\&As imply that they are, on average, to be found in larger locations compared to national M\&As.

Hypothesis 2b:

Higher entry costs for cross-border M\&As imply that they are, on average, to be found in locations that are nearby or give better access to larger locations compared to national M\&As.

Hypotheses 2a and 2b deal explicitly with locational features of the location. We will address these hypotheses by looking at three types of evidence by investigating the overall spatial concentration of M\&As in the USA (test of hypothesis 1), inspecting the location characteristics of M\&As (test of hypothesis 2a), and linking M\&A patterns to location determinants (test of hypothesis $2 \mathrm{~b}$ ).

\section{DATA SET}

The best and most extensive data source for M\&As is the 'Global Mergers and Acquisitions' database of Thomson Financial Securities Data (Thomson, hereafter). Our sample from the Thomson dataset starts in 1985 and runs until July 2012 (see also the Appendix for a detailed data description). We focus on all countries and selected those firms that merged with or took over a firm in the USA. Table 1 provides an overview of the resulting 192,281 M\&As that make up our sample. National M\&As

\footnotetext{
${ }^{7}$ So the condition $\tilde{\pi}_{c M}(c, M) \geq 0$ holds.

${ }^{8}$ We do not observe $c$, and concentrate on location choice.
} 
refer to an American-based firm merging or acquiring another American-based firm, whereas cross-border M\&As refer to firms from outside the US that take over a US based firm (not necessarily US-owned). Most M\&As are national rather than crossborder (86 per cent versus 14 per cent). ${ }^{9}$ We have information on the value of the transaction only in 45 per cent of the cases. In general, the larger the deal the more likely it is that there is information regarding the value of the transaction. Since crossborder M\&As are on average larger than national M\&As, this explains why the value of the transaction is available for 51 per cent of the cross-border M\&As compared to 44 per cent of the national M\&As. For both types of M\&As employment information is only provided for 10 per cent of the cases, while information on both value and employment is available for only 8 per cent of the M\&As.

Table 1 Overview of American M\&A data, 1985-2011

\begin{tabular}{l|cc|cc}
\hline \hline & National & $\%$ & Cross-border & $\%$ \\
\hline Total number of M\&As & 165,401 & 100 & 26,880 & 100 \\
With value of transaction & 72,561 & 44 & 13,688 & 51 \\
With employment data & 17,102 & 10 & 2,789 & 10 \\
Both value and employment data & 13,847 & 8 & 2,231 & 8
\end{tabular}

Total number of M\&As is 192,281 of which $14 \%$ is cross-border

Given the limited number of observations for which we have employment data available and the peculiarities of the employment data we will focus our attention on the M\&As for which the value of the transaction is available, which is also consistent with the definition of $V_{j}^{c b}\left(c, M_{j}\right)$. Figure 3 illustrates the geographic distribution of the national and cross-border M\&As. See the Appendix and section 5 for details of the geographical assignments. The size of the bubbles is proportional to the total value of M\&As in that location in the period 1985-2012. The contours and main locations of the United States are clearly visible from this geographical distribution. New York is the main location for M\&A targets, attracting 10.34 per cent of the value of national M\&As and 11.48 per cent of cross-border M\&As, see Table 2. For national M\&As New York is followed by Houston (4.01 per cent) and Chicago (3.85 per cent). For cross-border M\&As it is followed by San Francisco (5.36 per cent) and Chicago (3.99 per cent).

Comparing panels $a$ and $b$ in Figure 3 shows that there are both similarities and differences between national and cross-border M\&As, see also Table 2. Regarding the differences we note that there are many more locations visible for national M\&As than for cross-border M\&As (more dots: 5153 compared to 2046 locations, or 2.5

\footnotetext{
${ }^{9}$ Note, that our M\&A coverage is much larger than that of for instance Anand and Delios (2002) who have 2175 entries for the UK, Germany and Japan into the US.
} 
times as many). This is a consequence of the fact that there are many more national than cross-border M\&As (namely about 5.5 times as many), but also that cross-border M\&As might be more concentrated.

Figure 3 Geographic distribution of American national and cross-border M\&As

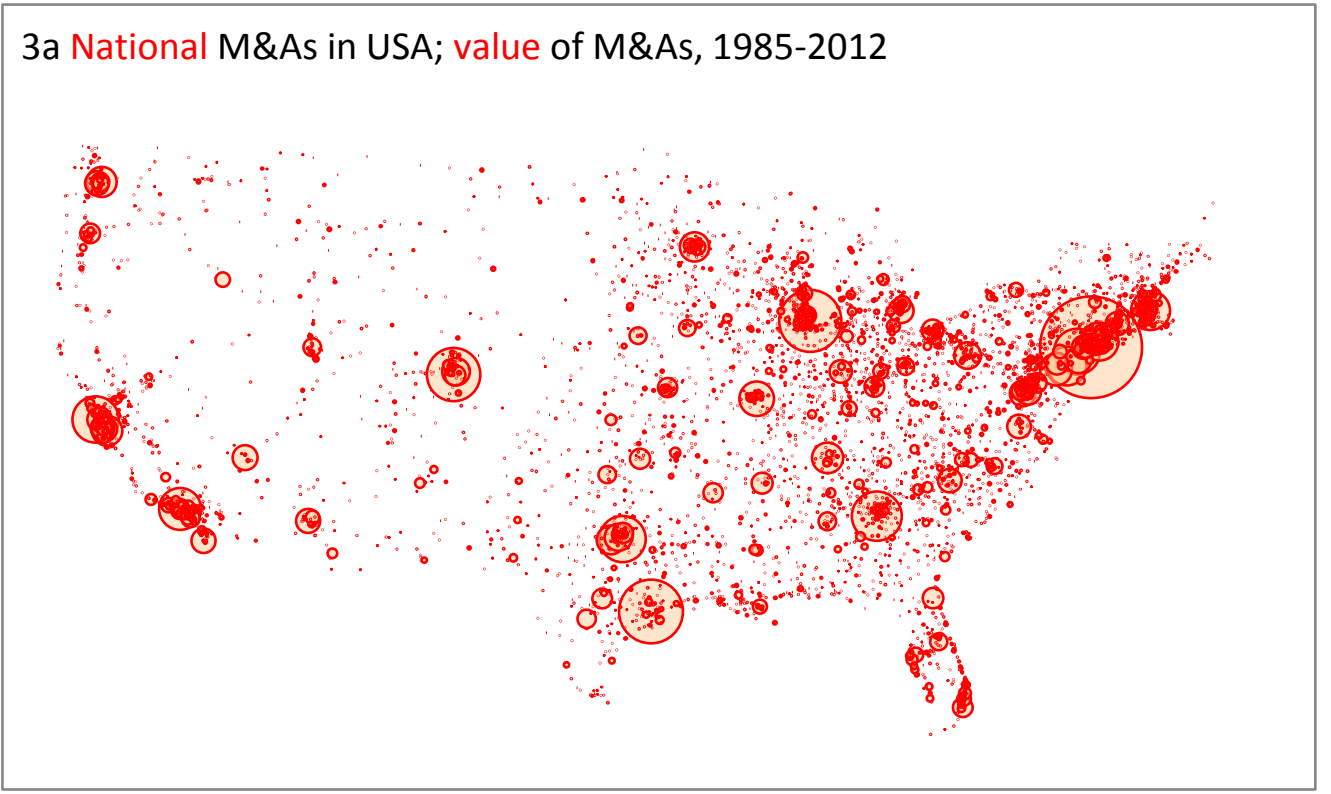

3b Cross-border M\&As in USA; value of M\&As, 1985-2012

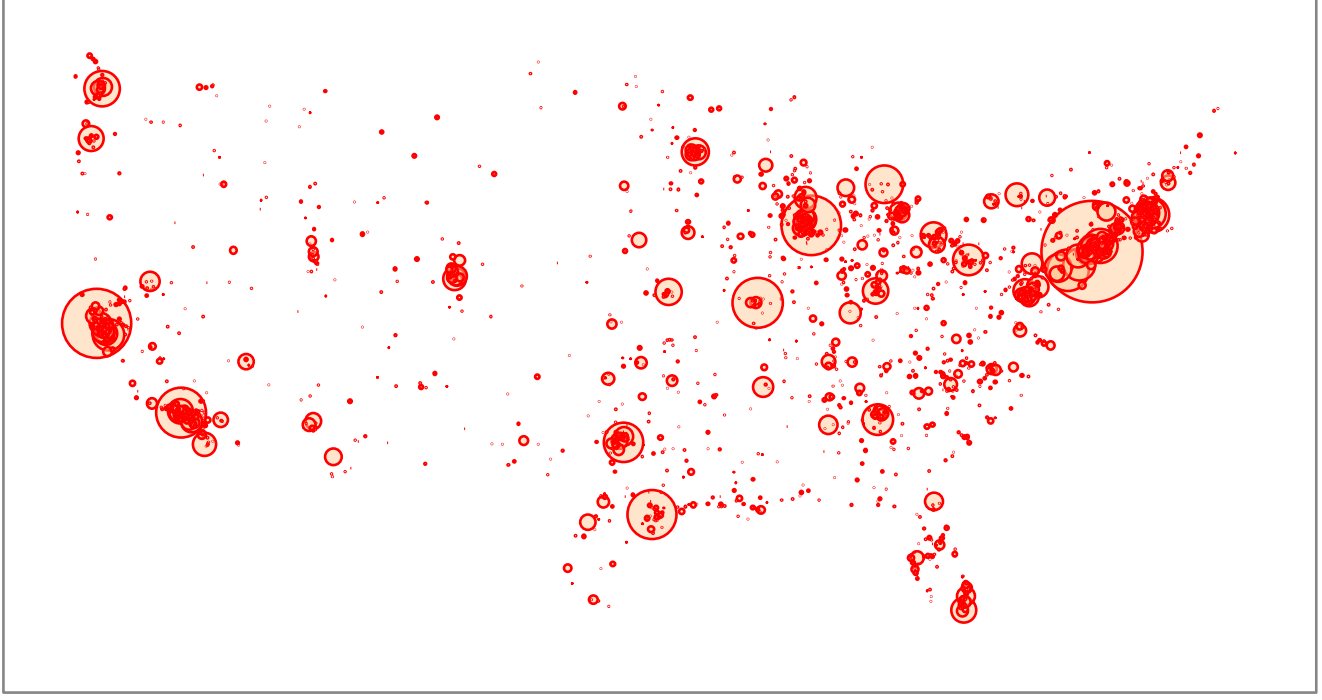

Table 2 provides the geographical distribution of the various types of M\&As across the 50 states and the District of Columbia, in number, value, and per cent of the respective total. The number of observations is reduced by about two per cent since we exclude the states "Guam”, "Virgin Islands", and "Unknown” from the analysis. The total value of the national M\&As (in constant 2010 dollars) is \$19.1 trillion, compared to $\$ 3.9$ trillion for cross-border M\&As. The average value for the national M\&As is therefore \$269 million, compared to \$291 million for cross-border M\&As. The largest target state for national M\&As is California, which attracts 16.2 per cent 
of the number of deals and 13.3 per cent of the total value. It is followed by Texas in terms of the number of deals and by New York in terms of total value.

Table 2 Distribution of M\&As with value of transaction across US states, 1985-2012

\begin{tabular}{|c|c|c|c|c|c|c|c|c|}
\hline \multirow[b]{3}{*}{ state } & \multicolumn{4}{|c|}{ total value and total number (\#) of M\&As } & \multicolumn{4}{|c|}{ percentile distribution of M\&As } \\
\hline & \multicolumn{2}{|c|}{ cross-border M\&As } & \multicolumn{2}{|c|}{ national M\&As } & \multicolumn{2}{|c|}{ cross-border M\&As } & \multicolumn{2}{|l|}{ national M\&As } \\
\hline & \# & value & \# & value & \# & value & \# & value \\
\hline$\overline{\mathrm{AK}}$ & 36 & 2 & 91 & 17 & 0.3 & 0.1 & 0.1 & 0.1 \\
\hline AL & 91 & 22 & 614 & 107 & 0.7 & 0.6 & 0.9 & 0.6 \\
\hline AR & 31 & 12 & 297 & 110 & 0.2 & 0.3 & 0.4 & 0.6 \\
\hline$A Z$ & 199 & 31 & 1,083 & 185 & 1.5 & 0.8 & 1.5 & 1.0 \\
\hline CA & 2,520 & 653 & 11,478 & 2,534 & 19.0 & 16.9 & 16.2 & 13.3 \\
\hline $\mathrm{CO}$ & 350 & 77 & 1,818 & 813 & 2.6 & 2.0 & 2.6 & 4.3 \\
\hline CT & 286 & 103 & 1,443 & 595 & 2.2 & 2.7 & 2.0 & 3.1 \\
\hline DC & 59 & 15 & 314 & 117 & 0.4 & 0.4 & 0.4 & 0.6 \\
\hline DE & 270 & 47 & 885 & 316 & 2.0 & 1.2 & 1.2 & 1.7 \\
\hline FL & 590 & 98 & 3,875 & 507 & 4.5 & 2.5 & 5.5 & 2.7 \\
\hline GA & 284 & 61 & 2,051 & 614 & 2.1 & 1.6 & 2.9 & 3.2 \\
\hline $\mathrm{HI}$ & 42 & 7 & 168 & 23 & 0.3 & 0.2 & 0.2 & 0.1 \\
\hline IA & 50 & 12 & 454 & 92 & 0.4 & 0.3 & 0.6 & 0.5 \\
\hline ID & 39 & 2 & 180 & 42 & 0.3 & 0.0 & 0.3 & 0.2 \\
\hline IL & 560 & 285 & 3,189 & 1,318 & 4.2 & 7.4 & 4.5 & 6.9 \\
\hline IN & 104 & 13 & 1,022 & 199 & 0.8 & 0.3 & 1.4 & 1.0 \\
\hline KS & 68 & 11 & 505 & 81 & 0.5 & 0.3 & 0.7 & 0.4 \\
\hline KY & 71 & 23 & 601 & 98 & 0.5 & 0.6 & 0.8 & 0.5 \\
\hline LA & 106 & 12 & 853 & 97 & 0.8 & 0.3 & 1.2 & 0.5 \\
\hline MA & 691 & 215 & 2,898 & 686 & 5.2 & 5.6 & 4.1 & 3.6 \\
\hline MD & 205 & 69 & 1,267 & 232 & 1.5 & 1.8 & 1.8 & 1.2 \\
\hline ME & 48 & 17 & 172 & 21 & 0.4 & 0.4 & 0.2 & 0.1 \\
\hline MI & 288 & 117 & 1,434 & 393 & 2.2 & 3.0 & 2.0 & 2.1 \\
\hline $\mathrm{MN}$ & 230 & 61 & 1,404 & 291 & 1.7 & 1.6 & 2.0 & 1.5 \\
\hline $\mathrm{MO}$ & 153 & 136 & 1,011 & 332 & 1.2 & 3.5 & 1.4 & 1.7 \\
\hline MS & 23 & 1 & 298 & 56 & 0.2 & 0.0 & 0.4 & 0.3 \\
\hline MT & 35 & 2 & 160 & 14 & 0.3 & 0.0 & 0.2 & 0.1 \\
\hline NC & 215 & 31 & 1,384 & 291 & 1.6 & 0.8 & 2.0 & 1.5 \\
\hline ND & 9 & 2 & 106 & 16 & 0.1 & 0.1 & 0.1 & 0.1 \\
\hline NE & 38 & 9 & 246 & 63 & 0.3 & 0.2 & 0.3 & 0.3 \\
\hline $\mathrm{NH}$ & 93 & 12 & 368 & 66 & 0.7 & 0.3 & 0.5 & 0.3 \\
\hline $\mathrm{NJ}$ & 572 & 211 & 2,602 & 1,103 & 4.3 & 5.5 & 3.7 & 5.8 \\
\hline NM & 43 & 3 & 298 & 39 & 0.3 & 0.1 & 0.4 & 0.2 \\
\hline NV & 236 & 27 & 696 & 130 & 1.8 & 0.7 & 1.0 & 0.7 \\
\hline NY & 1,323 & 573 & 5,768 & 2,462 & 10.0 & 14.8 & 8.1 & 12.9 \\
\hline $\mathrm{OH}$ & 343 & 99 & 2,217 & 482 & 2.6 & 2.6 & 3.1 & 2.5 \\
\hline OK & 90 & 21 & 822 & 168 & 0.7 & 0.5 & 1.2 & 0.9 \\
\hline OR & 103 & 28 & 600 & 108 & 0.8 & 0.7 & 0.8 & 0.6 \\
\hline PA & 509 & 182 & 2,808 & 673 & 3.8 & 4.7 & 4.0 & 3.5 \\
\hline RI & 47 & 19 & 199 & 26 & 0.4 & 0.5 & 0.3 & 0.1 \\
\hline SC & 78 & 12 & 538 & 76 & 0.6 & 0.3 & 0.8 & 0.4 \\
\hline SD & 10 & 3 & 86 & 8 & 0.1 & 0.1 & 0.1 & 0.0 \\
\hline TN & 140 & 36 & 1,004 & 335 & 1.1 & 0.9 & 1.4 & 1.8 \\
\hline TX & 1,072 & 272 & 6,758 & 1,923 & 8.1 & 7.0 & 9.5 & 10.1 \\
\hline UT & 135 & 11 & 598 & 81 & 1.0 & 0.3 & 0.8 & 0.4 \\
\hline VA & 267 & 49 & 1,713 & 534 & 2.0 & 1.3 & 2.4 & 2.8 \\
\hline VT & 15 & 2 & 114 & 10 & 0.1 & 0.0 & 0.2 & 0.1 \\
\hline WA & 277 & 91 & 1,245 & 435 & 2.1 & 2.4 & 1.8 & 2.3 \\
\hline WI & 123 & 52 & 830 & 143 & 0.9 & 1.3 & 1.2 & 0.7 \\
\hline WV & 28 & 3 & 243 & 32 & 0.2 & 0.1 & 0.3 & 0.2 \\
\hline WY & 43 & 2 & 165 & 12 & 0.3 & 0.1 & 0.2 & 0.1 \\
\hline$\overline{\text { total }}$ & 13,238 & 3,857 & 70,973 & 19,107 & 100 & 100 & 100 & 100 \\
\hline
\end{tabular}

We can already see at this aggregate level that the distribution of cross-border M\&As deviates from that of national M\&As. California is more popular among foreign firms, 
attracting 2.9 percentage points more deals than for national M\&As and 3.7 percentage points higher value. New York is also more popular among foreigners, with 1.9 percentage points more deals and 2.0 percentage point higher value. Texas, in contrast, is less popular among foreigners, with 1.4 percentage points fewer deals and 3.0 percentage points lower value. Taken over all states, the average absolute deviation in the percentile distribution for the number of deals is 0.38 percentage points and for the total value is 0.56 percentage points.

\section{SPATIAL CONCENTRATION OF M\&AS}

Method: Ellison-Glaeser index

In order to study concentration patterns a first step is to look at spatial concentration measures. This should reveal itself in a ranking of concentration; cross-border M\&As are expected to be more spatially concentrated than national M\&As, and M\&As in general are expected to be more concentrated than the overall location pattern of firms. We will measure the concentration of M\&As via the index introduced by Ellison and Glaeser (1997). The advantage of the EG index is that it corrects for industry or sector differences (see also Combes et al. (2008a). Some industries are highly specialized (the sector consists of a limited number of firms), while others consists of many firms. If an industry consists, for example, of 2 firms at most two regions account for all production, which could create the illusion of concentration; one should not mix specialization with concentration. ${ }^{10}$ We chose the EG-index as our starting point for the analysis, as it is one of the better indices (see also Holmes and Stevens, 2004).

$\gamma=\frac{\sum_{i}\left(s_{i}-x_{i}\right)^{2}-\left(1-\sum_{i} x_{i}^{2}\right) H}{\left(1-\sum_{i} x_{i}^{2}\right)(1-H)}$, where $H=\sum_{j} z_{j}^{2}$

$S_{i} \quad$ share of sector employment / value in United State i

$x_{i} \quad$ share of total employment / value in United State i

$H \quad$ Herfindahl index of employment / value size distribution for sector

In the absence of agglomeration effects some areas provide natural advantages that are better for some firms than for other firms. In this case, on average, the location of firms should resemble that of the overall distribution of employment; implying $\sum_{i}\left(s_{i}-x_{i}\right)^{2}$ is close to zero. Subtracting $\left(1-\sum_{i} x_{i}^{2}\right) H$ corrects for the fact that

\footnotetext{
10 Although the EG-index is a step forward it still is sensitive for administrative definitions of spatial units. Duranton and Overman $(2005,2008)$ correct for this, by abstracting from pre-defined spatial units by treating space as a continuum. A closely related measure to the EG index is the one developed by Maurel and Sédillot (1999).
} 
some industries consist of a limited number of ( large) firms, while others consist of a large number of firms. ${ }^{11}$

\section{Concentration results}

We focus on the value of M\&As, measured in constant 2010 dollars. Like EllisonGlaeser (1997) we analyze SIC sectors in a State, restricting attention for the moment to the 3-digit level. We have sector data available at the 4-digit SIC level. However, the number of transactions within the 4-digit classification is too limited. We thus restrict attention to 3-digit sectors or higher levels of aggregation. The underlying Herfindahl index per sector is based on the distribution of national M\&As in that sector. There are still very few observations (one or two) for certain 3-digit sectors, causing outliers in the EG index. We therefore apply the concommitant 2-digit sector Herfindahl index throughout our analysis. ${ }^{12}$ The Herfindahl index for the number of transactions is, of course, simply $1 / \mathrm{n}$, where $\mathrm{n}$ is the number of transactions in that sector. We use the number of M\&As as a robustness check.

11 Dividing the expression by $\left(1-\sum_{i} x_{i}^{2}\right)(1-H)$ gives an unbiased estimator of $\gamma$ (see Ellison and Glaeser, 1997). Furthermore, they show that $\gamma=\gamma^{n a}+\gamma^{S}-\gamma^{n a} \gamma^{S}$, where $\gamma^{n a}$ is a parameter capturing natural advantages, and $\gamma^{S}$ a parameter capturing the probability that a firm locates in the same location as its predecessor, indicating agglomeration advantages.

12 The correlation of the EG index using 2-digit and 3-digit Herfindahl indices is high (0.82 for crossborder M\&As, for example). Alternatively, we could impose a minimum number of observations before a sector is included in the analysis, reducing the number of included sectors. 
Table 3 Summary of Ellison-Glaeser concentration index; USA, 3-digit

\begin{tabular}{l|cc|cc}
\hline \hline & $\begin{array}{c}\text { Ellison- } \\
\text { Glaeser }\end{array}$ & $\begin{array}{c}\text { Holmes- } \\
\text { Stevens }\end{array}$ & $\begin{array}{c}\text { National } \\
\text { M\&As }\end{array}$ & $\begin{array}{c}\text { Cross-border } \\
\text { M\&As }\end{array}$ \\
\hline Minimum & -0.013 & -0.203 & -0.278 & -0.022 \\
Maximum & 0.630 & 0.909 & 1.157 & 1.311 \\
Mean & 0.051 & 0.034 & 0.219 & 0.421 \\
Median & 0.026 & 0.017 & 0.142 & 0.325 \\
\# Sectors & 459 & 1086 & 341 & 341
\end{tabular}

Source: Ellison and Glaeser (1997) data for establishment size, 4-digit SIC sectors; Holmes and Stevens (2004) data for establishment size, 6 digit NAICS sectors, mean and median are weighted averages by number of sectors; own calculations for M\&As based on 3 digit SIC sectors, 19852012. Areas refer to States of the US.

Table 3 summarizes our findings, both for national M\&As and cross-border M\&As. The minimum EG index for national M\&As is similar to that found by HolmesStevens and for cross-border M\&As to that found by Ellison-Glaeser. The maximum EG index for M\&As is somewhat higher in both cases. ${ }^{13}$ More importantly, however, the mean and median EG index for national M\&As (0.219 and 0.142, respectively) are significantly higher than for Ellison-Glaeser and Holmes-Stevens establishments, suggesting that national M\&As are more geographically concentrated than the distribution of establishments. As discussed above, we attribute this finding to the selection effect: only sufficiently successful and viable establishments are M\&A targets. Similarly, the mean and median EG index for cross-border M\&As (0.421 and 0.325, respectively) is significantly higher than for national M\&As. This indicates that the selection of establishments for cross-border M\&As is more stringent to overcome the higher costs to counteract the liability of foreign-ness (see equation 2).

Analyzing the more stringent selection effect for cross-border M\&As compared to national M\&As for the 341 sectors in more detail, we find that the cross-border EG index is higher than the national EG index for 267 sectors, or for 78.3 per cent of the cases. The average increase in the EG index is 0.202, almost a doubling of the value.

\footnotetext{
${ }^{13}$ For comparison purposes, the table restricts attention to sectors for which the EG index is available for both national and cross-border M\&As.
} 
Figure 4 PP-plot of EG indices; national M\&As - cross-border M\&As

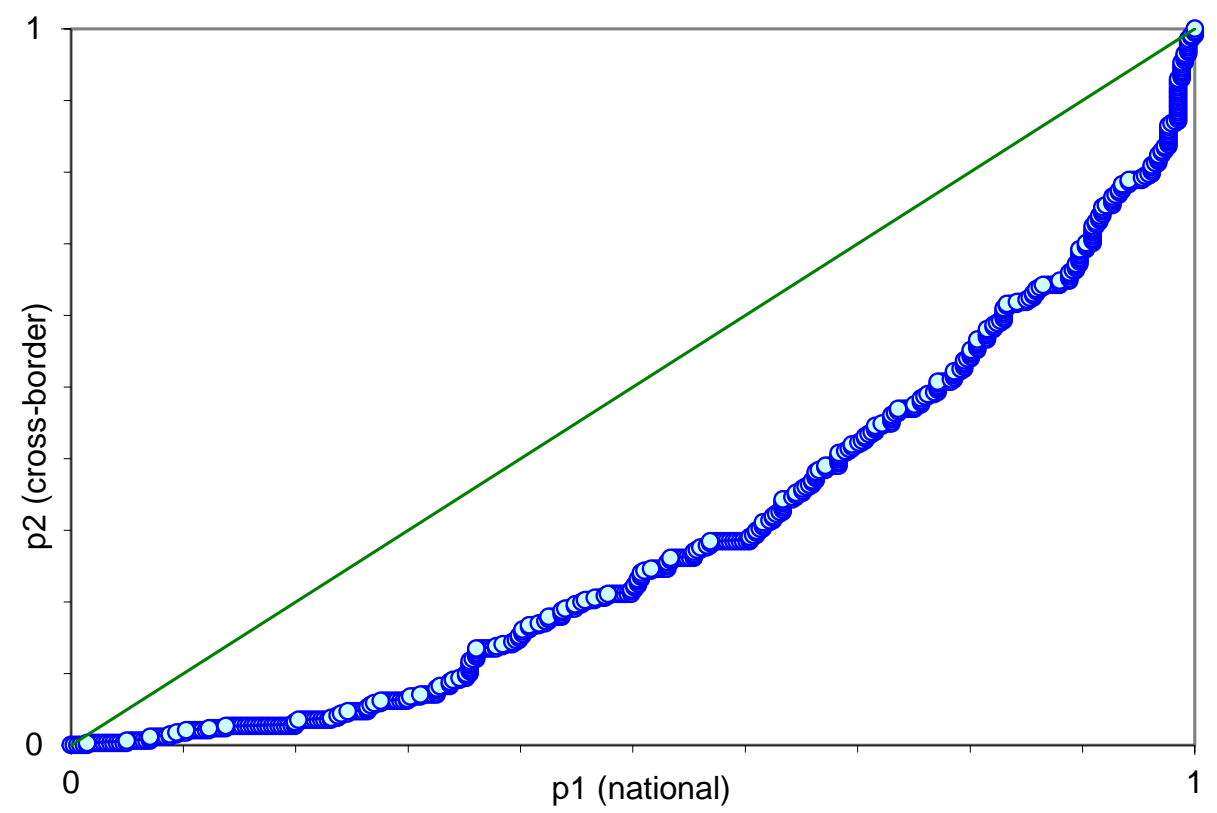

Test Statistics: Mean difference test: $9.48^{* * *}$, Distribution difference test: $2.749^{* * *}$ Where $* * *$ indicates the $1 \%$ significance level.

These differences are highly significant. To illustrate this we can compare the difference in the distributions of the EG indices, rather than focusing on a simple summary statistic such as the mean or variance. Figure 4 shows the percentilepercentile (PP) plot. This is the scatter plot of the percentiles of the two distributions, which focuses attention on the majority of the observations rather than possible outliers. If the two samples would have been drawn from the same underlying distribution the PP-plot would tend to coincide with the diagonal. Clearly, this is not the case. A formal test of the extent of the deviation of the PP-plot from the diagonal, provided by the HWM index (Hinloopen, et al., 2012), soundly rejects that the underlying distribution is the same (see Figure 4). Based on the above information, we may therefore conclude that the EG index for cross-border M\&As is significantly higher than for national M\&As.

\section{LOCATION OF M\&As WITHIN USA}

Method

We have established that cross-border M\&As are more concentrated than national M\&As (and that M\&As are more concentrated than US firms in general), but we do not know the locational features of the acquired firms. For all we know at this stage, they could be concentrated somewhere in a US desert. Our model in section 2 and in particular hypothesis 2a indicate that, compared to national M\&As, one expects crossborder M\&As to be found more often in larger locations across the USA because larger locations are associated with stronger market access or more general agglomeration rents and for cross-border M\&As to be profitable in a certain location, 
recall Figures 1 and 2, they require ceteris paribus larger agglomeration benefits to off-set the larger entry or location costs that they face.

The problem to be analyzed here is similar to the problem analyzed by Davis and Dingel (2014), building on the work of Costinot (2009). They analyze the sorting of skilled workers over a discrete number of cities with heterogeneous locations within the cities, which determines their productivity in different sectors. Davis and Dingel (2014) show that larger cities have relatively more skilled populations and produce relatively more in skill-intensive sectors. Instead of the sorting of workers with certain skills, we analyze the sorting of firms with certain (productivity/skill) characteristics regarding M\&As over a discrete number of locations within the cities determining their productivity in different sectors. Davis and Dingel (2014) provide two tests, an elasticity test, and a pairwise comparison test, which are both based on super modularity. A function $H$ (profits in our case) is supermodular (in our case in location size, L, and efficiency of firms engaged in M\&As: that is cross-border (CB) or national $(\mathrm{N}))$ if:

$$
L>L^{\prime}, C B>N \Rightarrow H(L, C B) H\left(L^{\prime}, N\right)>H(L, N) H\left(L^{\prime}, C B\right) .
$$

We assume that the efficiency of cross-border M\&As is larger than of national M\&As. If correct, the larger locations host relatively more of the (more productive) cross-border M\&As. Building on Davis and Dingel (2014) this can be tested in two ways via an elasticity test and a pairwise comparison test. The elasticity test compares the elasticities in the following simple regression:

$\ln (\mathrm{cb}, \mathrm{nat})=\beta_{0}+\beta_{i 1} \ln (L)+\epsilon$,

where, $i=c b, n$; the test checks whether $\beta_{c b, 1} \geq \beta_{n, 1}{ }^{14}$

The pairwise comparison test is directly related to super modularity.

We can compare any two arbitrary locations with the two M\&A types to see whether or not inequality for super modularity holds. If so, we verify that the larger location in this pairwise comparison has relatively more of the cross-border M\&A type. We call the comparison a 'success' if the condition holds (value $=1$ ) and a 'failure' if not (value $=0)$. We can thus compare for example 40 locations in $(40 \times 39) / 2=780$ different pairs, and each location pair has 2 M\&A types. This gives a total of $780 \times$ $2=1560$ pairwise comparisons. The extent to which the average success rate exceeds the random distribution benchmark of 0.5 can then be taken as an indication regarding the sorting-predictive power of the model. We can create different bins of locations. For instance a bin of 2, consisting of just of a group of large versus a group of small locations (consisting, for example, of a group of all locations larger than the median size, and a group smaller than the median size). In the analysis below we divide the locations into 2 up to 360 bins in discrete steps.

\footnotetext{
14 As shown in footnote 24 in Davis and Dingel (2014), this regression can be understood as a firstorder Taylor approximation where $\beta_{i 1}$ is increasing in $i$, due to the assumption of super modularity.
} 


\section{Test results}

Before we can perform such tests we have to assign M\&As to a specific location for which the relevant data are available, in this case by allocating all M\&As in our database to the nearest metropolitan statistical area (MSA). The Appendix describes the procedure in detail, and provides additional location characteristics. ${ }^{15}$

The elasticity test is illustrated in Figure 5 for both the number of M\&As (panel a) and the value of M\&As (panel b). The graphs illustrate the size of national and crossborder M\&As relative to the size of the population of the metropolitan areas, both in logs. The slope of the regression lines (which are also depicted) provide the elasticity of the size of M\&As (either in number or value) with respect to population size. In all cases M\&As tend to rise with population, but according to the elasticity test this rise should be faster for cross-border M\&As than for national M\&As. The slope of the cross-border regression line is indeed steeper for both the number of M\&As and the value of M\&As (in both panels of the figure). The cross-border estimates are also outside the 90 per cent confidence intervals of the national M\&A elasticity estimates, as summarized in Table 4.

\footnotetext{
15 The maximum distance of an M\&A location to the nearest MSA is $360 \mathrm{~km}$. We experimented with different maximum distances between M\&A and MSA for inclusion in the analysis, but this does not materially affect our results. We identify 361 MSAs with positive M\&A activity for the 48 contiguous states plus Washington DC.
} 
Figure 5 Elasticity test for cross-border M\&As versus national M\&As
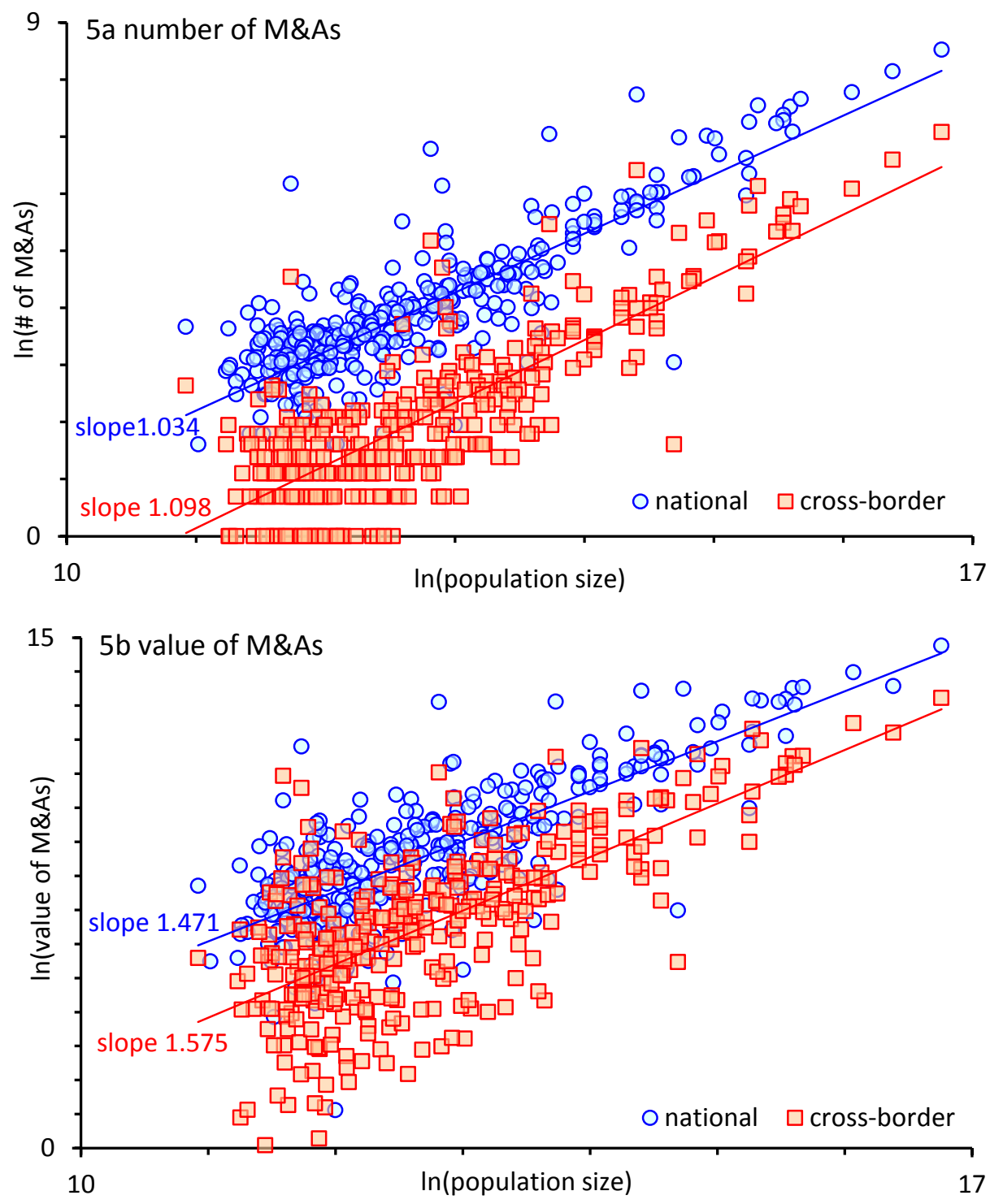

Based on M\&As within a $100 \mathrm{~km}$ radius of an MSA

Our findings do not change if we only allocate M\&As within a certain range to a specific metropolitan statistical area rather than including all M\&As without such a limit. This is illustrated for M\&As within a $100 \mathrm{~km}$ range in Table 4 and Figure 5.

Table 4 Metropolitan area elasticity test for M\&As, USA

\begin{tabular}{l|cc|cc}
\hline \hline & \multicolumn{2}{|c|}{ All M\&As included } & \multicolumn{2}{c}{ Only M\&As within 100 km } \\
& coefficient & st error & coefficient & st error \\
\hline Number M\&As, national & 0.971 & 0.0357 & 1.034 & 0.0343 \\
Number M\&As, cross-border & 1.057 & 0.0437 & 1.098 & 0.0420 \\
& 1.388 & 0.0614 & 1.471 & 0.0610 \\
Value M\&As, national & 1.520 & 0.0950 & 1.575 & 0.0882
\end{tabular}

The number of observations is 361 for national M\&As and 345 for cross-border if all M\&As are included; it is 360 and 338, respectively, if only M\&As within $100 \mathrm{~km}$ are included. 
The pairwise comparison test can best be illustrated by Figure 6, which shows the success rate of the pairwise comparison. The figure shows the un-weighted and the (population) weighted success rate. We expect that the successful comparison between a very large and a much smaller location is more revealing for the test than a comparison between two almost similar-sized locations for which the test outcome might just be a random result. We therefore include 'weighted' success rates, where we use the difference in log population for a location pair as weight.

Figure 6 Pairwise comparison; National and Cross-border M\&As

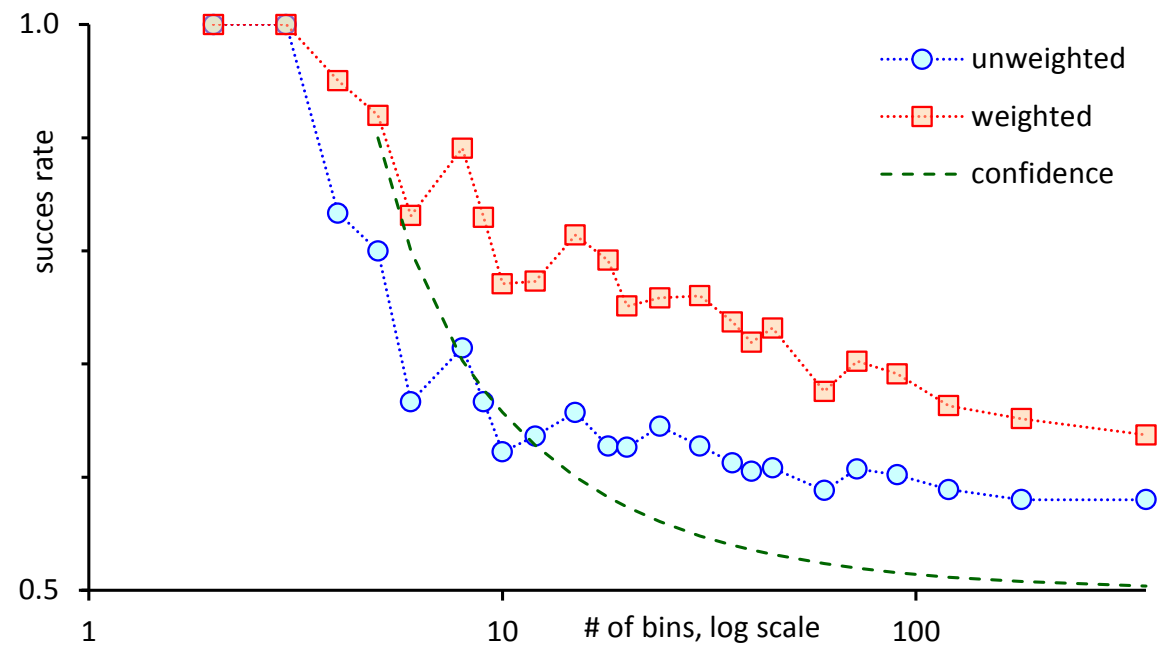

The confidence line indicates the upper limit of a 95\% confidence interval for tossing a fair coin; based on the central limit theorem above 27 pairs ( 8 bins) and exact below; not shown below 10 pairs ( 5 bins).

The benchmark is the horizontal axis at 0.5 , which would indicate a purely random result. The confidence line in the figure indicates the upper limit of a 95\% confidence interval for tossing a fair coin. The success rate for 2 and 3 bins is $100 \%$, both for the weighted and unweighted comparisons. The success rate decreases to a (weighted) success rate of $64 \%$ for 360 bins. For more than 10 bins both the weighted and unweighted bilateral comparisons are above the $95 \%$ confidence line. ${ }^{16}$ For all comparisons the success rate is better than the random outcome.

Based on the two tests in this section we can conclude that in line with our model and hypothesis 2a, cross-border M\&As are more often found in relatively large locations than national M\&As. This suggests that agglomeration economies are more important for cross-border M\&As. In the next section we address this question directly and also allow geography to play a role.

\footnotetext{
${ }^{16}$ Below that level there are essentially too few possibilities to construct a confidence interval; for 2 bins there is only 1 pair and for 3 bins there are only 2 pairs since we only have two categories (national and cross-border).
} 


\section{LOCATION DETERMINANTS OF CROSS-BORDER M\&AS}

Estimation method and model

We identify 5504 different locations receiving either national or cross-border M\&As in the observation period. We complement these locations with 1076 urban locations (urban areas of at least 2500 people in 2010) that did not receive any M\&As for a total of 6580 locations. We then link the location choices of M\&As to location characteristics of the 381 US Metropolitan Statistical Areas (MSA). ${ }^{17}$ In doing so we will not only take the features of the M\&A location as such into account but also, in line with hypothesis $2 \mathrm{~b}$, the economic geography of the location vis $a$ vis the rest of the USA (or the world). As we showed in our model set up, see Figure 2, some locations may not be viable for M\&A activity as they offer too little agglomeration benefits to overcome location costs. This is more stringent for cross-border M\&As; some locations that are viable for national M\&As might not be suitable for crossborder M\&As. In the estimations we should therefore explicitly deal with the issue of 'zero' observations. The percentage of observations with host MSA locations in the USA with zero M\&A activity in our sample period 1985-2012 is quite high, in particular for cross-border M\&As: 4534 out of 6580 for cross-border M\&As and 1427 out of 6580 for national M\&As. A proper handling of these zero observations is therefore important (see Santos-Silva and Tenreyro, 2006; Helpman et al. 2008; Razin and Sadka, 2007; Head and Mayer, 2014).

The zero observations problem can be dealt with by using Lambert's (1992) zeroinflated approach. This approach is similar to the Heckman et al. (2008) selection model but does not rely on the associated normality assumptions, and is therefore less restrictive (Heckman, 1974; see Razin and Sadka, 2007, for an application to FDI). ${ }^{18}$ The zero-inflated Poisson model assumes that there are two latent groups of observations; an observation in the always 0 Group, which has an outcome of 0 with a probability of 1 . We will label this the Passive Group. Observations in the other group which might have a zero outcome, but there is a positive probability that there is a non-zero outcome. We will label this the Active Group. This process is developed in two stages:

(i) Allocate membership into the latent groups (Passive Group and Active Group)

(ii) Model the value/number of (cross-border/national) M\&As for observations in the Active Group.

Based on the discussion in Head and Mayer (2014, section 5.2) we opt for the (zero inflated) Poisson model (ZIP). This approach can also be used for our non-integer

\footnotetext{
17 See the Appendix for further information on M\&As and the matching with MSAs. In general variables that involve distances are specific for M\&A locations (such as Market access), other variables link M\&As to the closest MSA.

18 This avoids the difficulty of trying to find an appropriate exclusion restriction (Helpman et al., 2008).
} 
data (the value of M\&As; see the discussion in Santos-Silva and Tenreyro (2006) for trade flows). Based on the definition of $V_{j}^{c b}\left(c, M_{j}\right)$ from our model, the dependent variable is the value of M\&As, the independent variables are related to (real) market access, $\mathrm{E}_{j} \mathrm{P}_{j}{ }^{(\sigma-1)}$. The location specific costs, $F_{j}$, are measured in terms of density (see step 2 in our model set up where we defined the profit function in a monopolistic competition setting). We capture real market access by a simple market access variable, as specific location dependent price indices are not available. Density related variables capture agglomeration economies of location $j$, but might also be related to congestion or, in our model terms, location costs of location $j$ (Glaeser, 2008). The additional fixed costs, $f$, for cross-border M\&As are implicitly captured by distinguishing between the zero and non-zero latent groups. Furthermore, we include several control variables, as well as (US federal state) fixed effects. Our approach is a natural complement to Head et al. (1995) who focus on greenfield FDI (see also Head and Mayer, 2004).

\section{Estimation results}

As a first step we differentiate between locations where M\&As takes place, that is cross-border and national M\&As combined versus locations where no M\&A activity takes place. The base-line estimation results are presented in Table $5 .{ }^{19}$ In general, we expect the coefficients of the variables in the passive group to be of opposite sign compared to the active group. We use clustered standard errors to allow for possible intra (target) State dependence. State fixed effects capture non-observed state relevant variables which might affect target selection. The number of zeros is listed for each regression. Vuong tests (not presented, but available upon request) indicate that the ZIP model is preferred over the Poisson model; we only present the results from the ZIP model.

Table 5 presents the results for the Passive group and the Active group. The columns with heading 'passive' describe the results of the equation that determines whether the observation is in the Passive Group (zero with probability 1) or not, the columns with headings MAtotval describe the Poisson regression to explain the total value of all M\&As. Four basic model specifications are presented: columns (1)-(2) show results for (real) market access; in columns (3)-(4) a dummy variable is added that indicates whether an international airport is available within 70 miles of the M\&A and captures international market access; colums (5)-(6) add population density as a measure of density related cost factors; and finally columns (7) and (8) includes all variables. Market access is measured as a simple Harris market potential for each of the M\&A locations, that is, a distance-weighted total income of all MSAs. ${ }^{20}$

\footnotetext{
19 All estimates are carried out with STATA, version 13.1. The do-files, and data files are available upon request. Table A.4 in the Appendix shows robustness of Table 5 without state fixed effect.

${ }^{20}$ Implicitly the distance decay has a coefficient of ' 1 ', experimenting with lower distance decay parameters does not affect the results in a qualitative sense (results available upon request).
} 
Table 5 M\&A locations versus No M\&A locations (the extensive margin)

\begin{tabular}{|c|c|c|c|c|c|c|c|c|}
\hline Variable & $\begin{array}{c}(1) \\
\text { MAtotval }\end{array}$ & $\begin{array}{c}\text { (2) } \\
\text { passive }\end{array}$ & $\begin{array}{c}\text { (3) } \\
\text { MAtotval }\end{array}$ & $\begin{array}{c}\text { (4) } \\
\text { passive }\end{array}$ & $\begin{array}{c}\text { (5) } \\
\text { MAtotval }\end{array}$ & $\begin{array}{c}(6) \\
\text { passive }\end{array}$ & $\begin{array}{c}\text { (7) } \\
\text { MAtotval }\end{array}$ & $\begin{array}{c}\text { (8) } \\
\text { passive }\end{array}$ \\
\hline $\begin{array}{l}\text { Market potential } \\
\text { Airport } 70 \\
\text { Population density } \\
\text { Constant }\end{array}$ & $\begin{array}{l}0.202^{* * *} \\
(5.58 \mathrm{e}-05)\end{array}$ & $\begin{array}{c}-0.490^{* * *} \\
(0)\end{array}$ & $\begin{array}{l}0.168^{* * *} \\
(0.00327) \\
1.464^{* * *} \\
(7.05 \mathrm{e}-05)\end{array}$ & $\begin{array}{c}-0.438^{* * *} \\
(0) \\
-0.675^{* * *} \\
(0.00641)\end{array}$ & $\begin{array}{c}0.253^{* * *} \\
(2.67 \mathrm{e}-08) \\
\\
-0.000118^{* * *} \\
(0.00369) \\
5.162^{* * *} \\
(0)\end{array}$ & $\begin{array}{c}-0.455^{* * *} \\
(0) \\
\\
-8.65 \mathrm{e}-05 \\
(0.176) \\
1.604^{* * *} \\
(1.83 \mathrm{e}-05)\end{array}$ & $\begin{array}{c}0.227^{* * *} \\
(1.34 \mathrm{e}-05) \\
1.621^{* * *} \\
(2.21 \mathrm{e}-07) \\
-0.000137^{* * *} \\
(7.35 \mathrm{e}-07) \\
5.380^{* * *} \\
(0)\end{array}$ & $\begin{array}{c}-0.415^{* * *} \\
(0) \\
-0.615^{* *} \\
(0.0102) \\
-6.95 \mathrm{e}-05 \\
(0.217) \\
1.280^{* * *} \\
(0.00211)\end{array}$ \\
\hline $\begin{array}{l}\text { Observations } \\
\text { State fixed effects } \\
\text { Number of zeroes }\end{array}$ & $\begin{array}{l}6,580 \\
\text { YES } \\
1076\end{array}$ & $\begin{array}{l}6,580 \\
\text { YES } \\
1076\end{array}$ & $\begin{array}{l}6,580 \\
\text { YES } \\
1076\end{array}$ & $\begin{array}{l}6,580 \\
\text { YES } \\
1076\end{array}$ & $\begin{array}{l}6,580 \\
\text { YES } \\
1076\end{array}$ & $\begin{array}{l}6,580 \\
\text { YES } \\
1076\end{array}$ & $\begin{array}{l}6,580 \\
\text { YES } \\
1076\end{array}$ & $\begin{array}{l}6,580 \\
\text { YES } \\
1076\end{array}$ \\
\hline
\end{tabular}

Robust pval in parentheses; ${ }^{* * *} \mathrm{p}<0.01,{ }^{* *} \mathrm{p}<0.05,{ }^{*} \mathrm{p}<0.1$; all estimates converged in one step; totval = total value; MA = Mergers \& Acquisitions 
A few results stand out. First, and foremost, market access is an important determinant for both the extensive margin of M\&As (active versus passive) as well as for the intensive margin. In all models, market access contributes positively to the probability of M\&As. The negative and highly significant coefficients in columns (2), (4), (6) and (8) indicate that a high market access makes it less likely for a location to be in the Passive Group of M\&As. High market access thus crucially affects whether a cross-border M\&A takes place at all, which is in line with hypothesis $2 b$. Once in the active group high market access positively contributes to higher values of M\&As in a particular location, as indicated by columns (1), (3), (5), and (7).

Second, location choice might be affected by nearby transportation possibilities, indicating international trade options or international market access from a USA location $j$ to the rest of the world. We experimented with distances to international oriented US seaports and airports. Table 5 shows the results for airports. The results for seaports were not significant and are not presented. The results in columns (3)-(4) and (7)-(8) show the positive contribution of a nearby international airport on the probability of M\&As. This indicates that the presence within a 70 mile radius of an internationally oriented airport is important. ${ }^{21}$ It matters for both the intensive and extensive margin. Results on population density seem only important for the intensive margin, as indicated by columns (5)-(6), and (7)-(8), and are less relevant for the extensive margin. We also experimented with controls, like unemployment, commuting time, international seaports, differentiating between coastal locations (east coast or west coast) or sunbelt locations and income per capita. Including these controls does not affect the baseline results described above.

In Table 6 we repeat the exercise but differentiate between the value of cross-border M\&As and national M\&As. The columns with heading 'Passive' again describe the results of the equation that determines whether the observation is in the Passive Group (zero with probability 1) or not, the columns with headings cbtotval and nattotval describe the Poisson regression to explain the value of the observations for crossborder and national M\&As respectively.

To a large extent the results mimic those of Table 5 for all M\&As. Again, market access for the extensive margin as well for the intensive margin of M\&As is important for both types of M\&As. The negative and highly significant coefficient in the Passive columns indicate that a high market access makes it less likely for the location to be in the Passive Group of M\&As. Second, for both cross-border and national M\&As international market access is important for both the intensive and extensive margin: better international market access means significantly more M\&A activity for the Active Group. Third, population density has a negative effect on the intensive margin but is not significant for the extensive margin.

\footnotetext{
21 The international airports in our sample are: Atlanta, Dallas, McCarran, Phoenix, Los Angeles, San Francisco, Denver, John F. Kennedy, LaGuardia, Newark, Logan, Philadelphia, Orlando, Atlanta, Miami, Charlotte, Minneapolis, O’Hare, Detroit, George Bush, Newark, Seattle.
} 
Table 6 National M\&A locations versus Cross-Border M\&A locations

\begin{tabular}{|c|c|c|c|c|c|c|c|c|}
\hline Variable & $\begin{array}{c}(1) \\
\text { nattotval }\end{array}$ & $\begin{array}{c}\text { (2) } \\
\text { passive }\end{array}$ & $\begin{array}{c}(3) \\
\text { cbtotval }\end{array}$ & $\begin{array}{c}\text { (4) } \\
\text { passive }\end{array}$ & $\begin{array}{c}(5) \\
\text { nattotval }\end{array}$ & $\begin{array}{c}(6) \\
\text { passive }\end{array}$ & $\begin{array}{c}(7) \\
\text { cbtotval }\end{array}$ & $\begin{array}{c}(8) \\
\text { passive }\end{array}$ \\
\hline $\begin{array}{l}\text { Market potential } \\
\text { Airport } 70 \\
\text { Constant }\end{array}$ & $\begin{array}{c}0.195^{* * *} \\
(0.000208) \\
5.359^{* * *} \\
(0)\end{array}$ & $\begin{array}{l}-0.251^{* * *} \\
(6.25 \mathrm{e}-05)\end{array}$ & $\begin{array}{c}0.175^{* * *} \\
(9.45 \mathrm{e}-09) \\
5.196^{* * *} \\
(0)\end{array}$ & $\begin{array}{c}-0.134^{* * *} \\
(0.000736) \\
2.306^{* * *} \\
(0)\end{array}$ & $\begin{array}{c}0.161^{* * *} \\
(0.00758) \\
1.507^{* * *} \\
(5.59 \mathrm{e}-05) \\
5.625^{* * *} \\
(0)\end{array}$ & $\begin{array}{c}-0.195^{* * *} \\
(0.00164) \\
-0.751^{* * *} \\
(6.69 \mathrm{e}-05) \\
-0.00221 \\
(0.996)\end{array}$ & $\begin{array}{c}0.159^{* * *} \\
(7.09 \mathrm{e}-06) \\
0.759^{* *} \\
(0.0277) \\
5.327^{* * *} \\
(0)\end{array}$ & $\begin{array}{c}-0.0856^{* * *} \\
(0.00824) \\
-0.827^{* * *} \\
(1.16 \mathrm{e}-08) \\
1.930^{* * *} \\
(0)\end{array}$ \\
\hline $\begin{array}{l}\text { Observations } \\
\text { State fixed effects } \\
\text { Number of zeroes }\end{array}$ & $\begin{array}{c}6,580 \\
\text { YES } \\
1427 \\
\end{array}$ & $\begin{array}{c}6,580 \\
\text { YES } \\
1427 \\
\end{array}$ & $\begin{array}{c}6,580 \\
\text { YES } \\
4534 \\
\end{array}$ & $\begin{array}{c}6,580 \\
\text { YES } \\
4534 \\
\end{array}$ & $\begin{array}{c}6,580 \\
\text { YES } \\
1427 \\
\end{array}$ & $\begin{array}{c}6,580 \\
\text { YES } \\
1427 \\
\end{array}$ & $\begin{array}{c}6,580 \\
\text { YES } \\
4534 \\
\end{array}$ & $\begin{array}{c}6,580 \\
\text { YES } \\
4534 \\
\end{array}$ \\
\hline Variables & $\begin{array}{c}(9) \\
\text { nattotval }\end{array}$ & $\begin{array}{c}\text { (10) } \\
\text { passive }\end{array}$ & $\begin{array}{c}\text { (11) } \\
\text { cbtotval }\end{array}$ & $\begin{array}{c}(12) \\
\text { passive }\end{array}$ & $\begin{array}{c}(13) \\
\text { nattotval }\end{array}$ & $\begin{array}{c}\text { (14) } \\
\text { passive }\end{array}$ & $\begin{array}{c}(15) \\
\text { cbtotval }\end{array}$ & $\begin{array}{c}\text { (16) } \\
\text { passive }\end{array}$ \\
\hline $\begin{array}{l}\text { Market potential } \\
\text { Airport } 70 \\
\text { Population density } \\
\text { Constant }\end{array}$ & $\begin{array}{c}-0.000118^{* * *} \\
(0.00293) \\
5.086^{* * *} \\
(0)\end{array}$ & $\begin{array}{c}9.32 \mathrm{e}-06 \\
(0.735) \\
0.457 \\
(0.278)\end{array}$ & $\begin{array}{c}-0.000115^{* * *} \\
(0.00480) \\
4.927^{* * *} \\
(0)\end{array}$ & $\begin{array}{l}3.22 \mathrm{e}-06 \\
(0.912) \\
2.321^{* * *} \\
(0)\end{array}$ & $\begin{array}{c}0.222^{* * *} \\
(5.42 \mathrm{e}-05) \\
1.662^{* * *} \\
(1.96 \mathrm{e}-07) \\
-0.000137^{* * *} \\
(1.92 \mathrm{e}-06) \\
5.307^{* * *} \\
(0)\end{array}$ & $\begin{array}{c}-0.205^{* * *} \\
(0.000322) \\
-0.760^{* * *} \\
(3.77 \mathrm{e}-05) \\
1.71 \mathrm{e}-05 \\
(0.467) \\
0.0573 \\
(0.895)\end{array}$ & $\begin{array}{c}0.213^{* * *} \\
(1.10 \mathrm{e}-08) \\
0.957^{* * *} \\
(0.00219) \\
-0.000130^{* * *} \\
(1.36 \mathrm{e}-06) \\
5.037^{* * *} \\
(0)\end{array}$ & $\begin{array}{c}-0.0968^{* * *} \\
(0.00861) \\
-0.846^{* * *} \\
(1.40 \mathrm{e}-09) \\
1.63 \mathrm{e}-05 \\
(0.398) \\
1.998^{* * *} \\
(0)\end{array}$ \\
\hline $\begin{array}{l}\text { Observations } \\
\text { State fixed effects } \\
\text { Number of zeroes }\end{array}$ & $\begin{array}{l}6,580 \\
\text { YES } \\
1427\end{array}$ & $\begin{array}{l}6,580 \\
\text { YES } \\
1427\end{array}$ & $\begin{array}{l}6,580 \\
\text { YES } \\
4534\end{array}$ & $\begin{array}{l}6,580 \\
\text { YES } \\
4534\end{array}$ & $\begin{array}{l}6,580 \\
\text { YES } \\
1427\end{array}$ & $\begin{array}{l}6,580 \\
\text { YES } \\
1427\end{array}$ & $\begin{array}{l}6,580 \\
\text { YES } \\
4534\end{array}$ & $\begin{array}{l}6,580 \\
\text { YES } \\
4534\end{array}$ \\
\hline
\end{tabular}

Robust pval in parentheses; ${ }^{* * *} \mathrm{p}<0.01,{ }^{* *} \mathrm{p}<0.05,{ }^{*} \mathrm{p}<0.1$; all estimates converged in one step; totval = total value; nat $=$ national; cb $=$ cross-border 
No clear difference is found between the results for cross-border versus national M\&As, which indicates that once a target location has been chosen - for cross-border M\&As relatively larger locations compared to national M\&As - market access, distance to an international airport, or population density are roughly equally important. Additional sensitivity analyses with controls, like unemployment, commuting time, differentiating between coastal locations or sunbelt locations, and income per capita, did not change the conclusions. We also experimented with our choice of location, see Table A.5 in the Appendix, by taking the so-called Urban locations as our spatial unit of analysis where we allocated all M\&As in a certain M\&A location to the Urban location with which it is linked, this gives us 3535 locations to be analyzed (2459 locations with M\&As and 1076 locations without M\&As) but this alternative specification of the spatial units also does not affect our conclusions. Finally, we investigated if locations close to the border are skewed because of Canadian and Mexican investments. ${ }^{22}$ We found that neither border affects the passive versus active decision. The Canadian border does not affect the size of M\&As either, whereas locations close to the Mexican have a lower value of M\&As, particularly for cross-border M\&As. ${ }^{23}$ This presumably indicates that M\&As close to the border are more likely to locate on the Mexican side of the border to benefit from lower labour cost while still having acces to the American market through NAFTA.

\section{CONCLUSIONS}

The bulk of FDI consists of cross-border M\&As. What has received scarce attention so far, in both the international economics and the international business literature, is the location of these M\&As within the host country. By explicitly adding the location pattern of M\&As, we can add to our understanding of M\&As because location patterns not only reveal where a merger or acquisition takes place, but also whether the location pattern of cross-border M\&As differs from national M\&As or from location patterns in general. Location selection is not random and we hypothesize, based on the work of Guadalupe et al. (2012), that cross-border acquirers are more selective than national acquirers, as they have to overcome larger market entry costs or, put differently, as they have to overcome the liability of foreignness.

To test our hypotheses, we analyze all manufacturing cross-border M\&As into the United States as well as all manufacturing national M\&As between 1985 and 2012. We provide three sets of empirical evidence. Using the Ellison-Glaeser index, we first find that M\&As are indeed more concentrated than firms in general, and that crossborder M\&As are even more concentrated, suggesting indeed that non-mobile

\footnotetext{
${ }^{22}$ We are grateful to Marius Bruehlhart for drawing our attention to this issue. We define the Canadian border as locations with latitude above 42 and the Mexican border as locations with latitude less than 35 and longitude less than -97 .

23 The Mexican border dummy is -1.126 for national M\&As and -1.402 for cross-border M\&As, translating to $2 / 3^{\text {rd }}$ to $3 / 4^{\text {th }}$ lower values, respectively. Both estimates are highly significant.
} 
location characteristics as suggested by Anand and Delios (2002) are important for the sorting mechanism determining target firm selection. Based on a novel test introduced by Davis and Dingel (2014), we then establish that cross-border M\&As are concentrated in larger agglomerations than national M\&As. These larger M\&As might offer higher agglomeration rents or provide better market access. Finally, we offer Zero Inflated Poisson estimates of the value of M\&As in particular locations, which in the first stage distinguishes between a group where no M\&As take place (but do have targets) and locations that are attractive for M\&As. In the second stage the intensive margin of M\&As is determined. We show that the distinction between locations for cross-border M\&As and national M\&As is particularly important for the first stage: locations need a good market access and access to a nearby international airport in order to be eligible for cross-border M\&A activity, also after controlling for location specific variables. Locations close to the Mexican border have lower M\&As.

\section{REFERENCES}

Alfaro, L., and M. X. Chen (2014), The Global Agglomeration of Multinational Firms, Journal of International Economics, Forthcoming, doi:

10.1016/j.jinteco.2014.09.001

Anand, J., and A. Delios (2002), Absolute and Relative Resources as Determinants of International Acquisitions, Strategic Management Journal, Vol. 23, pp. 119-134.

Antras, P., and S.R. Yeaple (2014), Multinational Firms and the Structure of International Trade, in: G. Gopinath, E. Helpman, and K. Rogoff, Handbook of International Economics, Vol.4, Elsevier, North-Holland, Amsterdam, pp. 55-130.

Baldwin, R., and T. Okubo (2006), Heterogeneous Firms, Agglomeration and Economic Geography: Spatial Selection and Sorting, Journal of Economic Geography, Vol. 6, pp. 323-346.

Basile, R., D. Castellani, and A. Zanfei, (2008), Location Choices of Multinational firms in Europe: The Role of EU cohesion policy, Journal of International Economics, Vol.74, pp. 328-340.

Bertrand, O., and H. Zitouna (2006), Trade liberalization and industrial restructuring: the role of cross-border mergers and acquisitions, Journal of Economics and Management Strategy, 15: pp. 479-515.

Beugelsdijk, S, Ph. McCann, and R. Mudambi (2010), Introduction: Place, Space and Organization: Economic Geography and the Multinational Enterprise, Journal of Economic Geography, 10(4), pp. 485-493

Brakman, S., H. Garretsen, C. van Marrewijk, and A. van Witteloostuijn (2013), Cross-Border Merger \& Acquisition acticvity and revealed Comparative Advantage in Manufacturing Industries, Journal of Economics \& Management Strategy, Vol. 22(1), pp. 28-57. 
Brakman, S., H. Garretsen, and C. van Marrewijk (2007), Cross-border mergers and acquisitions: the facts as a guide for international economics, in: G. Gregoriou and L. Renneboog (eds.), International Mergers and Acquisitions Activity since 1990: Recent Research and Quantitative Analysis, Academic Press/Elsevier, Cambridge MA, pp. 23-49.

Brakman, S, H. Garretsen and C. van Marrewijk (2009), The New Introduction to Geographical Economics, Cambridge University Press, Cambridge UK.

Blonigen, B.A., R.B. Davies, G.R. Waddell, and H.T. Naughton (2007), FDI in Space: spatial autoregressive relationships in foreign direct investment, European Economic Review, Vol.51, pp. 1303-1325.

Blonigen, B., L. Fontagné, N. Sly, and F. Toubal (2014), Cherries for Sale: The incidence of Cross-Border M\&A, Journal of International Economics, doi: 10.1016/j.jinteco.2014.08.005.

Bobonis, G.J., and H.J. Shatz (2007), Agglomeration, Adjustment, and State Policies in the Location of Foreign Direct Investment in the United States, Review of Economics and Statistics, Vol. 89, pp. 30-43.

Brülhart, M., and N.A. Mathys (2008), Sectoral agglomeration economies in a panel of European Regions, Regional Science and Urban Economics, Vol. 38, pp. 348-362.

Combes, P-P, T. Mayer, and J-F Thisse (2008a), Economic Geography: The Integration of Regions and Nations, Princeton University Press, Princeton.

Combes P-P, G. Duranton, and L. Gobillon (2008b), Spatial wage disparities: sorting matters, Journal of Urban Economics, Vol. 63, pp. 723-742.

Combes, P-P, G. Duranton, L. Gobillon, D. Puga, and S. Roux (2012), The Poductivity Advantages of large Cities: Distinguishing Agglomeration from Firm Selection, Econometrica, Vol. 80, pp. 2543-2594.

Costinot, A. (2009), An elementary theory of comparative advantage, Econometrica 77(4), pp. 1165-1192.

Costinot, A. and J.Vogel (2015), Beyond Ricardo: Assignment Models in International Trade, Annual Review of Economics, Vol. 7, pp.31-62.

Davis, D.R., and J.I. Dingel (2014), The comparative advantage of cities, NBER Working Paper No. 20602, Cambridge Mass.

De la Roca, J., and D. Puga (2012), Learning in Big Cities, CEPR discussion paper, No 9243, London.

Defever, F. (2006), Functional fragmentation and the location of multinational firms in the enlarged Europe, Regional Science \&Urban Economics, Vol.36, pp. 658-677.

Dunning, J.H. (2000), The Eclectic Paradigm as an Envelope for Economic and Business Theories of Multinational Activity, International Business Review, 9, pp. 163-190. 
Duranton, G., and H. Overman (2005), Testing for location using micro-geographic data, Review of Economic Studies, Vol.72, pp. 1077-1106.

Duranton, G., and H. Overman (2008), Exploring the Detailed Location Patterns of U.K. Manufacturing Industries using Microgeographic Data, Journal of Regional Science, 48(1), pp. 213-243.

Ellison, G., and E.L. Glaeser (1997), Geographic Concentration in U.S. Manufacturing Industries: A Dartboard Approach, Journal of Political Economy, 105(5), pp. 889-927.

Ellison, G., and E.L. Glaeser (1999), The Geographic Concentration of Industry: Does Natural Advantage Explain Agglomeration? American Economic Review Papers and Proceedings, 89(2), pp. 311-316.

Egger, P., and F.R. Hahn (2010), Endogenous bank mergers and their impact on banking performance: some evidence from Austria, International Journal of Industrial Organization, 28, pp. 155-166.

Evenett, S.J. (2004), The cross-border mergers and acquisitions wave of the late 1990s, in: R.E. Baldwin and L.A. Winters (eds.), Challenges to Globalization: Analyzing the Economics, The University of Chicago Press, Chicago and London, pp. 411-467.

Fontagne, M., and T. Mayer (2005), Determinants of Location Choices by Multinational Firms: A Review of the Current State of Knowledge, Applied Economics Quarterly, Vol.51, Supplement, pp. 9-34.

Fumagalli, E., and H. Vasconcelos (2009), Sequential cross-border mergers, International Journal of Industrial Organization, 27, pp. 175-187.

Glaeser, E.L. (2008), Cities, Agglomeration and Spatial Equilibrium, Oxford University Press, Oxford.

Guadalupe, M., O. Kuzmina, and C. Thomas, (2012), Innovation and Foreign Ownership, American Economic Review, Vol. 102, pp. 3594-3627.

Halvorsen, T. (2012), Size Location and Agglomeration of Inward Foreign Direct Investment (FDI) in the United States, Regional Studies, Vol. 46, pp. 660-682.

Head, K., J. Ries, and D. Swenson (1995), Agglomeration benefits and Location choice: Evidence from Japanese manufacturing investments in the United States.

Head, K., J. Ries, and D. Swenson (1999), Attracting foreign manufacturing: investment promotion and agglomeration, Regional Science and Urban Economics, Vol. 29, pp. 197-218.

Head, K., and T. Mayer (2004), Market Potential and the Location of Japanese Investment in the European Union, Review of Economics and Statistics, 86:959-972. 
Head, K., and T. Mayer (2014), Gravity Equation: Workhorse, Toolkit, and Cookbook, in: G. Gopinath, E. Helpman, and K. Rogoff, Handbook of International Economics, Vol.4, pp.131-195.

Heckman, J. J. (1974), Sample Selection Bias as a Specification Error, Econometrica, 42, pp. 153-168.

Helpman, E., M. Melitz, and S. Yeaple (2004), Exports versus FDI with Heterogeneous Firms, American Economic Review, 2004, 94(1), pp. 300-316.

Helpman, E., M. Melitz, and Y. Rubenstein (2008), Estimating trade flows: Trading partners and trading volumes, Quarterly Journal of Economics, Vol. 123, pp. 441487.

Hinloopen, J., R. Wagenvoort, and C. van Marrewijk (2012), A k-sample homogeneity test: the Harmonic Weighted Mass index, International Econometric Review, 4(1), pp. 17-39.

Holmes, T.J., and J.J. Stevens (2004), Spatial Distribution of Economic Activities in North America, in J.V. Henderson, and J-F Thisse (eds.), Handbook of Regional and Urban Economics, Vol.4, North-Holland, Elsevier, Amsterdam.

Iammarino, S and Ph McCann (2013) Multinationals and Economic Geography: Location, Technology and Innovation, Edward Elgar, Cheltenham, UK.

Kim, S-H, T.S. Pickton, and S. Gerking (2003), Foreign Direct Investment: Agglomeration Economies and Returns to Promotion Expenditures, The Review of Regional Studies, Vol. 33, pp. 61-72.

Lambert, Diane (1992), Zero-Inflated Poisson Regression, with an Application to Defects in Manufacturing, Technometrics, Vol. 34, pp.1-14.

Mataloni, R.J. (2011), The structure of location choice for new U.S. manufacturing investments in Asia-Pacific, Journal of World Business, Vol.46, pp.154-165.

Maurel, F., and B. Sédillot (1999), A measure of Geographical concentration of French manufacturing Industry, Regional Science and Urban Economics, Vol. 29, pp. 575-604.

Melitz, M.J. (2003), The impact of trade on intra-industry reallocations and aggregate industry productivity, Econometrica, 71, pp. 1695-1725.

Melo, P., D.J. Graham, and R.B. Noland (2009), A meta-analysis of estimates of urban agglomeration economies, Regional Science and Urban Economics, 39, pp. 332-342.

Mrázová, M., and J.P. Neary (2013), Selection Effects with Heterogeneous firms, Mimeo, Oxford University: http://www.economics.ox.ac.uk/Department-ofEconomics-Discussion-Paper-Series/selection-effects-with-heterogeneous-firms 
Neary, J.P. (2004), Monopolistic competition and international trade theory, in: S. Brakman and B.J. Heijdra (eds.), The Monopolistic Competition Revolution in Retrospect, Cambridge University Press, Cambridge, pp. 159-184.

Neary, J.P. (2007), Cross-border mergers as instruments of comparative advantage, Review of Economic Studies, 74, pp. 1229-1257.

Nocke, V., and S. Yeaple (2007), Cross-border mergers and acquisitions vs Greenfield foreign direct investment: The role of firm heterogeneity, Journal of International Economics, Vol. 72, pp. 336-365.

Nocke, V., and S. Yeaple (2008), An Assignment theory of Foreign Direct Investment, Review of Economic Studies, Vol. 75, pp. 529-557.

O’Brien, D.P., and G. Shaffer (2005), Bargaining, bundling, and clout: the portfolio effects of horizontal mergers, RAND Journal of Economics, 36, pp. 573-595.

Razin, A., and E. Sadka (2007), Foreign Direct Investment, Princeton University Press, Princeton.

Salant, S., S. Switzer, and R. Reynolds (1983), Losses from horizontal merger: the effects of an exogenous change in industry structure on Cournot-Nash Equilibrium, Quarterly Journal of Economics, 98, pp. 185-199.

Santos-Silva, J., and S. Tenreyro (2006), The Log of Gravity, The Review of Economics and Statistics, 88(4), pp. 641-658. 


\section{APPENDIX DATA DESCRIPTION}

\section{Data}

The best and most extensive data source for M\&As is the 'Global Mergers and Acquisitions' database of Thomson Financial Securities Data (Thomson, hereafter). Our sample from the Thomson dataset starts in 1985 and runs until July 2012. We focus on all countries and selected those firms that merged with or took over a firm in the USA. National M\&As refer to an American-based firm merging or acquiring another American-based firm, whereas cross-border M\&As refer to firms from outside the US that take over a US based firm (not necessarily US-owned). We have information on the value of the transaction only in 45 per cent of the cases. In general, the larger the deal the more likely it is that there is information regarding the value of the transaction. Since cross-border M\&As are on average larger than national M\&As, this explains why the value of the transaction is available for 51 per cent of the crossborder M\&As compared to 44 per cent of the national M\&As. For both types of M\&As employment information is only provided for 10 per cent of the cases, while information on both value and employment is available for only 8 per cent of the M\&As. We focus our attention on the M\&As for which the value of the transaction is available.

\section{M\&A location matching}

To provide more detailed information on the location of M\&As we matched the Thomson data with geographic information (longitude and latitude). As a starting point, we took the 86,249 M\&As for which the value of the transaction is known, see Table A1 for details. Of these M\&As Thomson provides the "city" as well as the state for about 83 per cent of the observations. Restricting attention to the 48 contiguous states and Washington DC reduces the number of M\&As to 71,038 observations (82 per cent of the total).

Table A1 Geographic matching of M\&As

\begin{tabular}{l|cc|cc|cc} 
& National & $\%$ & Cross-border & $\%$ & Total & $\%$ \\
\hline With value & 72,561 & 100 & 13,688 & 100 & 86,249 & 100 \\
With value and city & 60,266 & 83 & 11,034 & 81 & 71,300 & 83 \\
48 contiguous states + DO & 60,055 & 83 & 10,983 & 80 & 71,038 & 82 \\
Geographically matched & 59,961 & 83 & 10,963 & 80 & 70,924 & 82
\end{tabular}

We used location information on about 43,500 locations provided to us by University of Groningen (available upon request), to connect the state and city in the Thomson data to longitude and latitude coordinates. We manually corrected the information where needed and possible in about 9000 cases (10 per cent of the total). In most cases this involved correction of spelling errors, such as "Birmingham" instead of "Bermingham" in Alabama or "Phoenix" instead of "Phoeniz" in Arizona. In other cases we needed to delete a comma or excess information, such as the " $\mathrm{N}$ " in " $\mathrm{N}$ Hollywood" California. When the location could not be matched directly, we used 
Google earth, and allocated it to a nearby big(ger) city. The location "Newbury Park" in California, for example, is thus allocated to "Thousand Oaks." In case the "city" refers to a wider area, such as the "Piceance basin" in Colorado or the "Gulf of Mexico" in Texas we looked up this area on Google or used common knowledge to allocate it to a central location within the area, in casu "Meeker" and "Corpus Christi," respectively. In some exceptional cases (114 times, 0.1 per cent of the total) we were not able to allocate the M\&A to any location in particular. This happened, for example, for "California" and "Lakeview Terrace" in the state of California and for "Suite 630" in Minnesota. These cases are excluded from our further analysis. As Table A1 indicates, there is little difference in the success rate of matching to specific locations between national M\&As and cross-border M\&As.

\section{Urban location matching}

The 2010 US Census identifies 3592 Urban locations, consisting of 497 'Urban Areas' (population $\geq 50,000$ ) and 3095 'Urban Clusters' (population from 2,500 to $50,000)$. Together the Urban locations account for about 253 million people or about 82 percent of the total American population. From now on we ignore the 57 Urban locations in Alaska, Hawaii, and Puerto Rico and concentrate on the 3535 remaining Urban locations. The largest Urban Area is New York - Newark (18.35 million), followed by Los Angeles - Long Beach - Anaheim (12.15 million) and Chicago (8.61 million), see Figure A.1 for an overview of the distribution of population size for the Urban locations.

Figure A.1 Population size of Urban locations

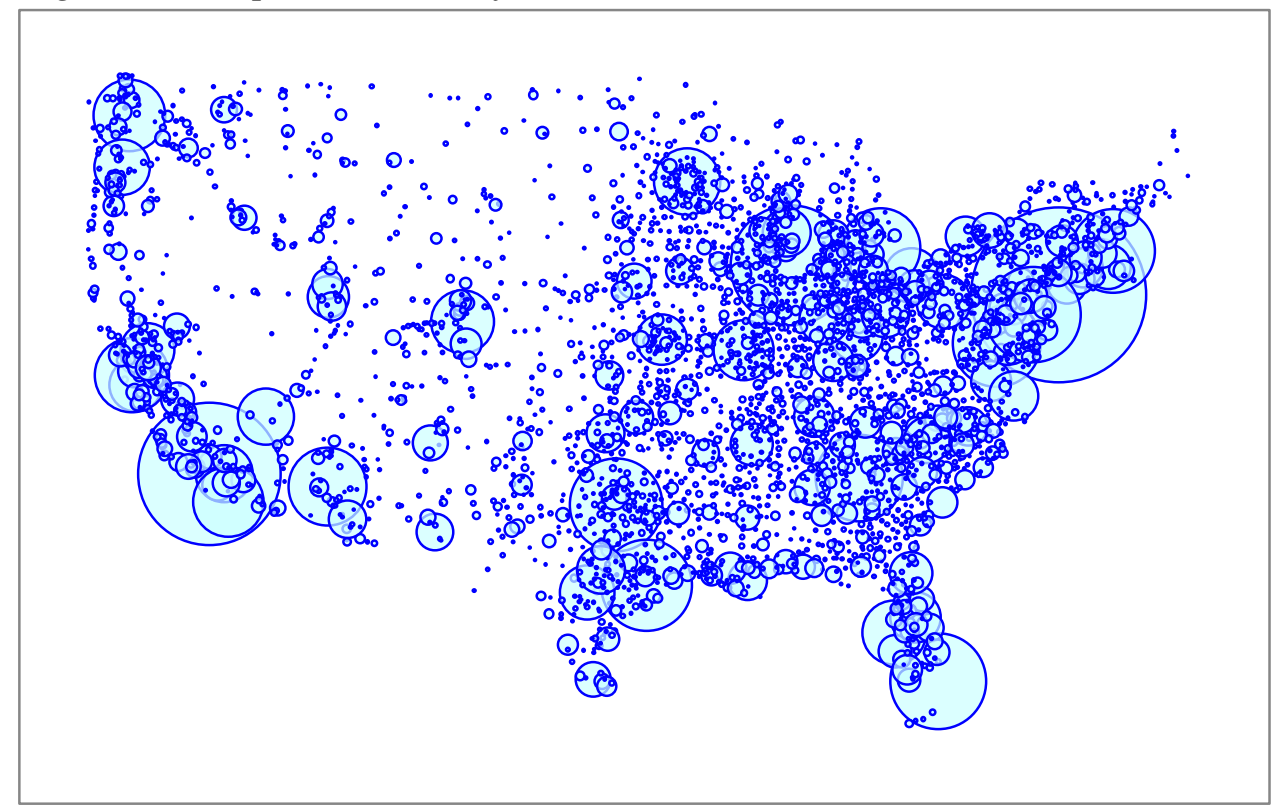

We link M\&A locations to Urban locations in two steps. First, for all M\&A locations we check if there is an Urban location with the same name. If so, we link the M\&A location to this Urban location and impose a distance of zero between the two 
locations. ${ }^{24}$ Second, for the remaining M\&A locations we calculate the minimum distance from this location to all Urban locations using latitude and longitude. We link the M\&A location to the nearest Urban location while recording the distance between the two locations. Using this procedure the 5504 M\&A locations are linked to 2459 different Urban locations. This implies that the remaining 1076 Urban locations do not have any M\&A location linked to them. They can be found throughout the country, as illustrated in Figure A.3.

Figure A.2 Urban locations with (circle, light) and without (square, dark) M\&As

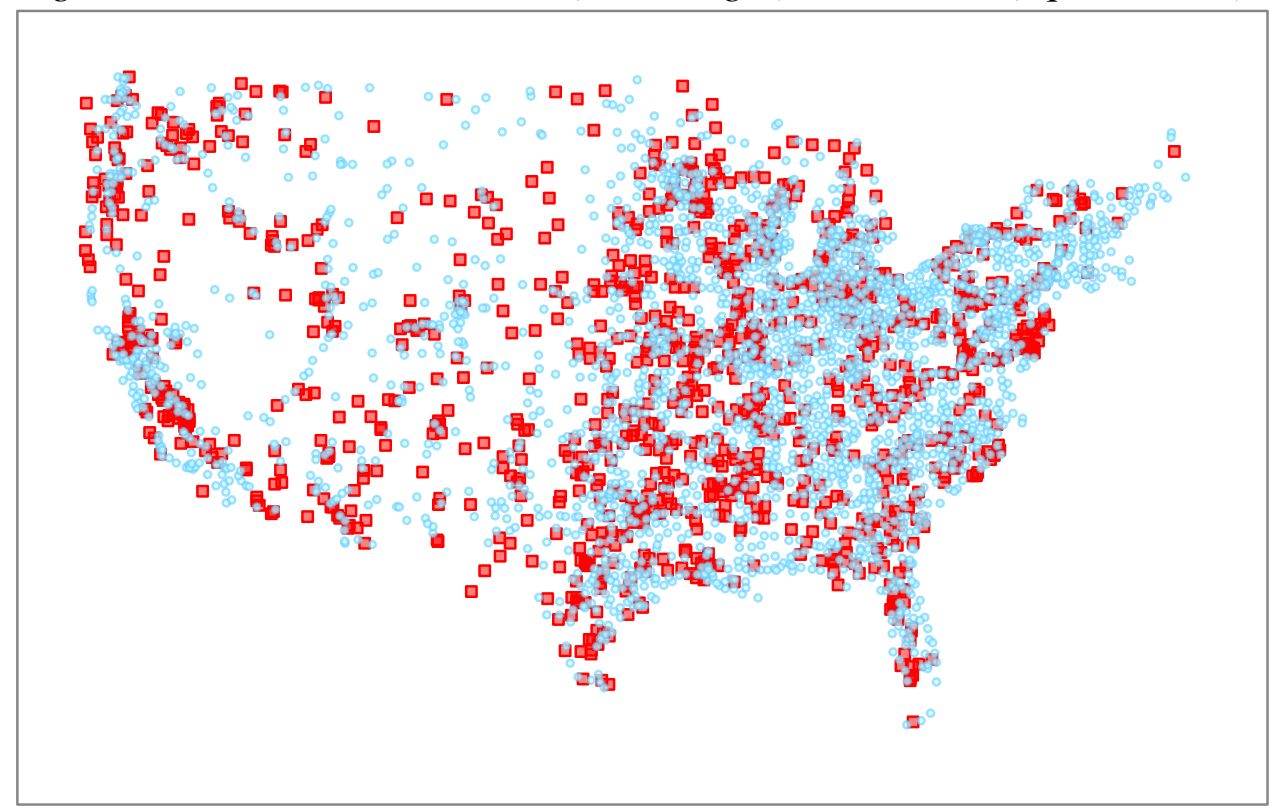

Our estimation procedure can now, in principle, proceed in two different ways.

- First, we can take the 5504 M\&A locations as a point of departure and identify the location-specific characteristics that make them attractive for M\&As. We then add the 1076 Urban locations without any M\&A links and their location-specific characteristics. The total number of locations is thus $5504+1076=6580$.

- Second, we can take the Urban locations as our point of departure. We then allocate all M\&As in a certain M\&A location to the Urban location with which it is linked. This gives us 3535 locations to be analyzed, namely 2459 locations with M\&As and 1076 locations without M\&As.

The main paper evaluates the results of the first approach, while providing the results of the second approach as a robustness check.

Table A.3 provides a description of the variables used and the relevant sources.

\footnotetext{
${ }^{24}$ This happens for 1799 M\&A locations.
} 
Table A.3 Variable definitions and sources

\begin{tabular}{|c|c|c|}
\hline Variable & Description & Source \\
\hline nat tot \# & $\begin{array}{l}\text { The number of M\&A targets with value } \\
\text { information available at a given location } \\
\text { taken over by national (American) firms in } \\
\text { the period } 1985 \text { - July } 2012\end{array}$ & $\begin{array}{l}\text { Thomson Financial Securities } \\
\text { matched with University of } \\
\text { Groningen location data }\end{array}$ \\
\hline cb tot \# & $\begin{array}{l}\text { The number of M\&A targets with with value } \\
\text { information available at a given location } \\
\text { taken over by foreign firms in the period } \\
1985 \text { - July } 2012\end{array}$ & $\begin{array}{l}\text { Thomson Financial Securities } \\
\text { matched with University of } \\
\text { Groningen location data }\end{array}$ \\
\hline nat tot val & $\begin{array}{l}\text { The real value in } 2010 \text { \$ million (using GDP } \\
\text { deflator) of the nat tot \# variable M\&A } \\
\text { targets at a given location taken over by } \\
\text { national (American) firms in the period } 1985 \\
\text { - July } 2012\end{array}$ & $\begin{array}{l}\text { Thomson Financial Securities } \\
\text { matched with University of } \\
\text { Groningen location data }\end{array}$ \\
\hline cb tot val & $\begin{array}{l}\text { The real value in } 2010 \text { \$ million (using GDP } \\
\text { deflator) of the cb tot \# variable M\&A } \\
\text { targets at a given location taken over by } \\
\text { foreign firms in the period } 1985 \text { - July } 2012\end{array}$ & $\begin{array}{l}\text { Thomson Financial Securities } \\
\text { matched with University of } \\
\text { Groningen location data }\end{array}$ \\
\hline MSA dist & $\begin{array}{l}\text { Distance from M\&A location (or urban } \\
\text { location) to nearest MSA location in km; } \\
\text { connection with relevant MSA variables }\end{array}$ & $\begin{array}{l}\text { Calculated based on } \\
\text { coordinates, US Census } \\
\text { Bureau and } \\
\text { Proximityone.com }\end{array}$ \\
\hline airp dist & $\begin{array}{l}\text { Distance in km from M\&A location (or } \\
\text { urban location) to nearest main airport, list } \\
\text { of } 20 \text { busiest airports by total passenger } \\
\text { boardings in } 2010 \text { for } 48 \text { states + DC }\end{array}$ & $\begin{array}{l}\text { Calculated based on } \\
\text { coordinates, IATA } \\
\text { (www.iata.org/) }\end{array}$ \\
\hline seap dist & $\begin{array}{l}\text { Distance in km from M\&A location (or } \\
\text { urban location) to nearest main seaport, list } \\
\text { of } 20 \text { busiest seaports in } 2010 \text { for } 48 \text { states + } \\
\text { DC }^{25}\end{array}$ & $\begin{array}{l}\text { Calculated based on } \\
\text { coordinates, American } \\
\text { Association of Port } \\
\text { Authorities (http://www.aapa- } \\
\text { ports.org/) }\end{array}$ \\
\hline MP Harris & $\begin{array}{l}\text { Market potential of M\&A location (or urban } \\
\text { location) based on distance to all MSAs; } \\
\text { sum of all MSA income in US \$ billion in } \\
2010 \text { with distance decay }=-1 \text {; internal } \\
\text { distance }\left(\left(\frac{2}{3}\right) \sqrt{(\text { area } / \pi)}\right) \text { is used if bigger } \\
\text { than distance based on coordinates }\end{array}$ & $\begin{array}{l}\text { Calculated based on } \\
\text { coordinates, US Census } \\
\text { Bureau and } \\
\text { Proximityone.com }\end{array}$ \\
\hline MP 0.9 & Same as above with distance decay $=-0.9$ & \\
\hline $\begin{array}{l}\text { Urban } \\
\text { location }\end{array}$ & $\begin{array}{l}\text { List of } 3592 \text { urban locations (urban areas } \\
\text { and urban clusters) in USA with at least } \\
2500 \text { inhabitants in 2010; variables: } \\
\text { Longitude in decimals } \\
\text { Latitude in decimals } \\
\text { Population size in } 2010 \\
\text { Land area in square km }\end{array}$ & US Census Bureau \\
\hline
\end{tabular}

\footnotetext{
${ }^{25}$ We used the ports of: Mobile, Lake Charles, Baton Rouge, Long Beach, Los Angeles, Twin Ports, Houston, New York, Baltimore, Tampa, Huntington, Beaumont, Louisiana, New Orleans, Hampton, Pittsburg, Philadelphia, Corpus Christi, Tampa, Texas Citi. The ranking is relatively robust over the years, although at the bottom end of the ranking some changes can occur.
} 
Table A.3 continued

MSA List of 374 Metropolitan Statistical Areas in Proximityone.com

USA, 2011; variables:

Longitude in decimals

Latitude in decimals

Population size in 2010

Population size in 2000

Land area in square mile

Population weighted density in 2010

E002, EMPLOYMENT STATUS - In labor force

E003, EMPLOYMENT STATUS - In labor force - Civilian labor force

E005, EMPLOYMENT STATUS - In labor force - Civilian labor force -

Unemployed

E025, COMMUTING TO WORK - Mean travel time to work (minutes)

E032, INDUSTRY - Civilian employed population 16 years and over

E033, INDUSTRY - Agriculture, forestry, fishing and hunting, and mining

E034, INDUSTRY - Construction

E035, INDUSTRY - Manufacturing

E036, INDUSTRY - Wholesale trade

E037, INDUSTRY - Retail trade

E038, INDUSTRY - Transportation and warehousing, and utilities

E039, INDUSTRY - Information

E040, INDUSTRY - Finance and insurance, and real estate and rental and

leasing

E041, INDUSTRY - Professional, scientific, and management, and

administrative and waste management services

E042, INDUSTRY - Educational services, and health care and social

assistance

E043, INDUSTRY - Arts, entertainment, and recreation, and accommodation

and food services

E044, INDUSTRY - Other services, except public administration

E045, INDUSTRY - Public administration

E048, CLASS OF WORKER - Government workers

E051, INCOME AND BENEFITS - Total households

E062, INCOME AND BENEFITS - Median household income (dollars)

E063, INCOME AND BENEFITS - Mean household income (dollars)

E068, INCOME AND BENEFITS - With retirement income

E088, INCOME AND BENEFITS - Per capita income (dollars)

E092, INCOME AND BENEFITS - Median earnings for workers (dollars)

E093, INCOME AND BENEFITS - Median earnings for male full-time, yearround workers (dollars)

E094, INCOME AND BENEFITS - Median earnings for female full-time, year-round workers (dollars)

E119, PERCENT OF FAMILIES/PEOPLE WHOSE INCOME IN PAST 12

MONTHS IS BELOW POVERTY LEVEL - All families 
Table A.4 Robustness: Table 5 without state fixed effects

\begin{tabular}{|c|c|c|c|c|c|c|c|c|}
\hline Variable & $\begin{array}{c}\text { (1) } \\
\text { MAtotval }\end{array}$ & $\begin{array}{c}(2) \\
\text { passive }\end{array}$ & $\begin{array}{c}(3) \\
\text { MAtotval }\end{array}$ & $\begin{array}{c}(4) \\
\text { passive }\end{array}$ & $\begin{array}{c}(5) \\
\text { MAtotval } \\
\end{array}$ & $\begin{array}{c}(6) \\
\text { passive }\end{array}$ & $\begin{array}{c}(7) \\
\text { MAtotval }\end{array}$ & $\begin{array}{c}\text { (8) } \\
\text { passive }\end{array}$ \\
\hline $\begin{array}{l}\text { Market potential } \\
\text { Airport } 70 \\
\text { Population density } \\
\text { Constant }\end{array}$ & $\begin{array}{c}0.0707^{* * *} \\
(0.00169)\end{array}$ & $\begin{array}{c}-0.267^{* * *} \\
(0)\end{array}$ & $\begin{array}{c}0.0394 \\
(0.136) \\
1.657^{* * *} \\
(4.65 \mathrm{e}-08)\end{array}$ & $\begin{array}{c}-0.236^{* * *} \\
(0) \\
-1.066^{* * *} \\
(7.08 \mathrm{e}-05)\end{array}$ & $\begin{array}{c}0.119^{* * *} \\
(0.000208) \\
\\
-6.70 \mathrm{e}-05^{* *} \\
(0.0160) \\
6.992^{* * *} \\
(0)\end{array}$ & $\begin{array}{c}-0.250^{* * *} \\
(0) \\
\\
-0.000133^{* * *} \\
(0.00359) \\
0.814^{* * *} \\
(0.00556)\end{array}$ & $\begin{array}{c}0.112^{* * *} \\
(0.000182) \\
1.803^{* * *} \\
(0) \\
-0.000103^{* * *} \\
(1.77 \mathrm{e}-06) \\
6.470^{* * *} \\
(0)\end{array}$ & $\begin{array}{c}-0.231^{* * *} \\
(0) \\
-0.911^{* * *} \\
(0.000197) \\
-8.51 \mathrm{e}-05^{*} \\
(0.0515) \\
0.620^{* *} \\
(0.0260)\end{array}$ \\
\hline $\begin{array}{l}\text { Observations } \\
\text { State fixed effects } \\
\text { Number of zeroes }\end{array}$ & $\begin{array}{l}6,580 \\
\text { NO } \\
1076\end{array}$ & $\begin{array}{l}6,580 \\
\text { NO } \\
1076\end{array}$ & $\begin{array}{l}6,580 \\
\text { NO } \\
1076\end{array}$ & $\begin{array}{l}6,580 \\
\text { NO } \\
1076\end{array}$ & $\begin{array}{l}6,580 \\
\text { NO } \\
1076\end{array}$ & $\begin{array}{l}6,580 \\
\text { NO } \\
1076\end{array}$ & $\begin{array}{l}6,580 \\
\text { NO } \\
1076\end{array}$ & $\begin{array}{l}6,580 \\
\text { NO } \\
1076\end{array}$ \\
\hline
\end{tabular}

Robust pval in parentheses; ${ }^{* * *} \mathrm{p}<0.01,{ }^{* *} \mathrm{p}<0.05,{ }^{*} \mathrm{p}<0.1$; all estimates converged in one step; totval = total value; MA = Mergers \& Acquisitions 
Table A.5 Urban Location sensitivity: M\&A locations versus No M\&A locations (the extensive margin)

\begin{tabular}{|c|c|c|c|c|c|c|}
\hline Variables & $\begin{array}{c}(1) \\
\text { MAtotval }\end{array}$ & $\begin{array}{c}(2) \\
\text { passive }\end{array}$ & $\begin{array}{c}(3) \\
\text { nattotval }\end{array}$ & $\begin{array}{c}(4) \\
\text { passive }\end{array}$ & $\begin{array}{c}(5) \\
\text { cbtotval }\end{array}$ & $\begin{array}{c}\text { (6) } \\
\text { passive }\end{array}$ \\
\hline Market potential & $\begin{array}{l}0.300^{* * *} \\
(0.00267)\end{array}$ & $\begin{array}{l}-0.254^{* * *} \\
(4.21 \mathrm{e}-09)\end{array}$ & $\begin{array}{l}0.308^{* * *} \\
(0.00247)\end{array}$ & $\begin{array}{l}-0.255^{* * *} \\
(5.98 \mathrm{e}-10)\end{array}$ & $\begin{array}{l}0.219^{* * *} \\
(0.00541)\end{array}$ & $\begin{array}{l}-0.429^{* * *} \\
(0.000149)\end{array}$ \\
\hline Airport 70 & $\begin{array}{l}2.143^{* * *} \\
(4.78 \mathrm{e}-06)\end{array}$ & $\begin{array}{c}-0.359^{* *} \\
(0.0433)\end{array}$ & $\begin{array}{l}2.128^{* * *} \\
(1.99 \mathrm{e}-05)\end{array}$ & $\begin{array}{c}-0.372^{* *} \\
(0.0146)\end{array}$ & $\begin{array}{l}1.715^{* * *} \\
(6.19 \mathrm{e}-07)\end{array}$ & $\begin{array}{c}-0.484^{* *} \\
(0.0200)\end{array}$ \\
\hline Population density & $\begin{array}{c}-6.52 \mathrm{e}-05 \\
(0.264)\end{array}$ & $\begin{array}{c}-2.62 \mathrm{e}-05 \\
(0.257)\end{array}$ & $\begin{array}{c}-7.32 \mathrm{e}-05 \\
(0.216)\end{array}$ & $\begin{array}{c}-3.17 \mathrm{e}-05 \\
(0.187)\end{array}$ & $\begin{array}{c}-1.24 \mathrm{e}-05 \\
(0.873)\end{array}$ & $\begin{array}{c}1.66 \mathrm{e}-06 \\
(0.966)\end{array}$ \\
\hline Constant & $\begin{array}{c}5.523^{* * *} \\
(0)\end{array}$ & $\begin{array}{l}0.667^{* *} \\
(0.0441)\end{array}$ & $\begin{array}{c}5.371^{* * *} \\
(0)\end{array}$ & $\begin{array}{l}0.995^{* * *} \\
(0.00164)\end{array}$ & $\begin{array}{c}5.144^{* * *} \\
(0)\end{array}$ & $\begin{array}{l}4.175^{* * *} \\
(9.76 \mathrm{e}-07)\end{array}$ \\
\hline Observations & 3,535 & 3,535 & 3,535 & 3,535 & 3,535 & 3,535 \\
\hline State fixed effects & YES & YES & YES & YES & YES & YES \\
\hline Number of zeroes & 1076 & 1076 & 1173 & 1173 & 2570 & 2570 \\
\hline
\end{tabular}

Robust pval in parentheses; ${ }^{* * *} \mathrm{p}<0.01,{ }^{* *} \mathrm{p}<0.05,{ }^{*} \mathrm{p}<0.1$; all estimates converged in one step; totval = total value; $\mathrm{MA}=$ Mergers \& Acquisitions; nat = national; cb = crossborder 